Prepared in cooperation with the Onondaga Lake Partnership

\title{
Improvement in Precipitation-Runoff Model Simulations by Recalibration With Basin-Specific Data, and Subsequent Model Applications, Onondaga Lake Basin, Onondaga County, New York
}

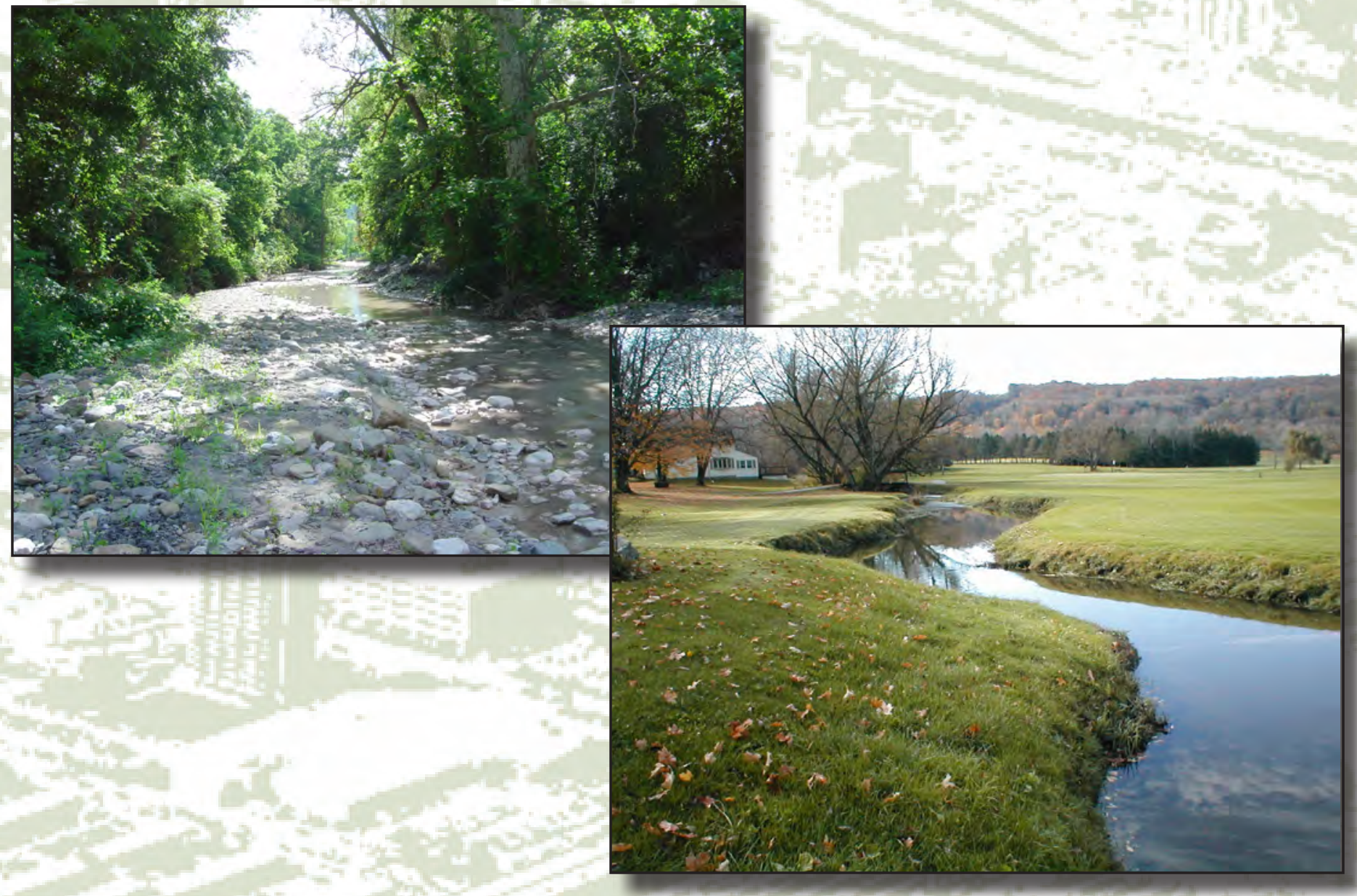

Scientific Investigations Report 2011-5203 
Cover. Background image showing aerial view of downtown Syracuse, N.Y., taken by William Hecht. Photographs of streams in the Onondaga Lake Basin. 


\section{Improvement in Precipitation-Runoff \\ Model Simulations by Recalibration With \\ Basin-Specific Data, and Subsequent \\ Model Applications, Onondaga Lake Basin, \\ Onondaga County, New York}

By William F. Coon

Prepared in cooperation with the Onondaga Lake Partnership

Scientific Investigations Report 2011-5203 


\section{U.S. Department of the Interior \\ KEN SALAZAR, Secretary \\ U.S. Geological Survey \\ Marcia K. McNutt, Director}

U.S. Geological Survey, Reston, Virginia: 2011

For more information on the USGS - the Federal source for science about the Earth, its natural and living resources, natural hazards, and the environment, visit http://www.usgs.gov or call 1-888-ASK-USGS.

For an overview of USGS information products, including maps, imagery, and publications, visit http://www.usgs.gov/pubprod

To order this and other USGS information products, visit http://store.usgs.gov

Any use of trade, product, or firm names is for descriptive purposes only and does not imply endorsement by the U.S. Government.

Although this report is in the public domain, permission must be secured from the individual copyright owners to reproduce any copyrighted materials contained within this report.

Suggested citation:

Coon, W.F., 2011, Improvement in precipitation-runoff model simulations by recalibration with basin-specific data, and subsequent model applications, Onondaga Lake Basin, Onondaga County, New York: U.S. Geological Survey Scientific Investigations Report 2011-5203, 37 p., at http://pubs.usgs.gov/sir/2011/5203/. 


\section{Acknowledgments}

Thanks are extended to Jeanne Powers, Antonio Deskins, and Janaki Suryadevara of the Onondaga County Department of Water Environment Protection (OCWEP) for their assistance in providing water-quality data from sites in OCWEP's Ambient Monitoring Program and miscellaneous data on chloride concentrations in the Onondaga Lake Basin. Mark Murphy, manager of the Onondaga County Water Authority water-treatment plant near Marcellus, New York, provided data on Otisco Lake water levels and withdrawals, as well as precipitation data. Greg Crysler, operator of the Marcellus wastewater-treatment plant, provided water-quality data for Ninemile Creek near the plant.

Lisa Senior and Rheannon Hart, both of the U.S. Geological Survey, conducted technical reviews of the report. 
THIS PAGE INTENTIONALLY LEFT BLANK 


\section{Contents}

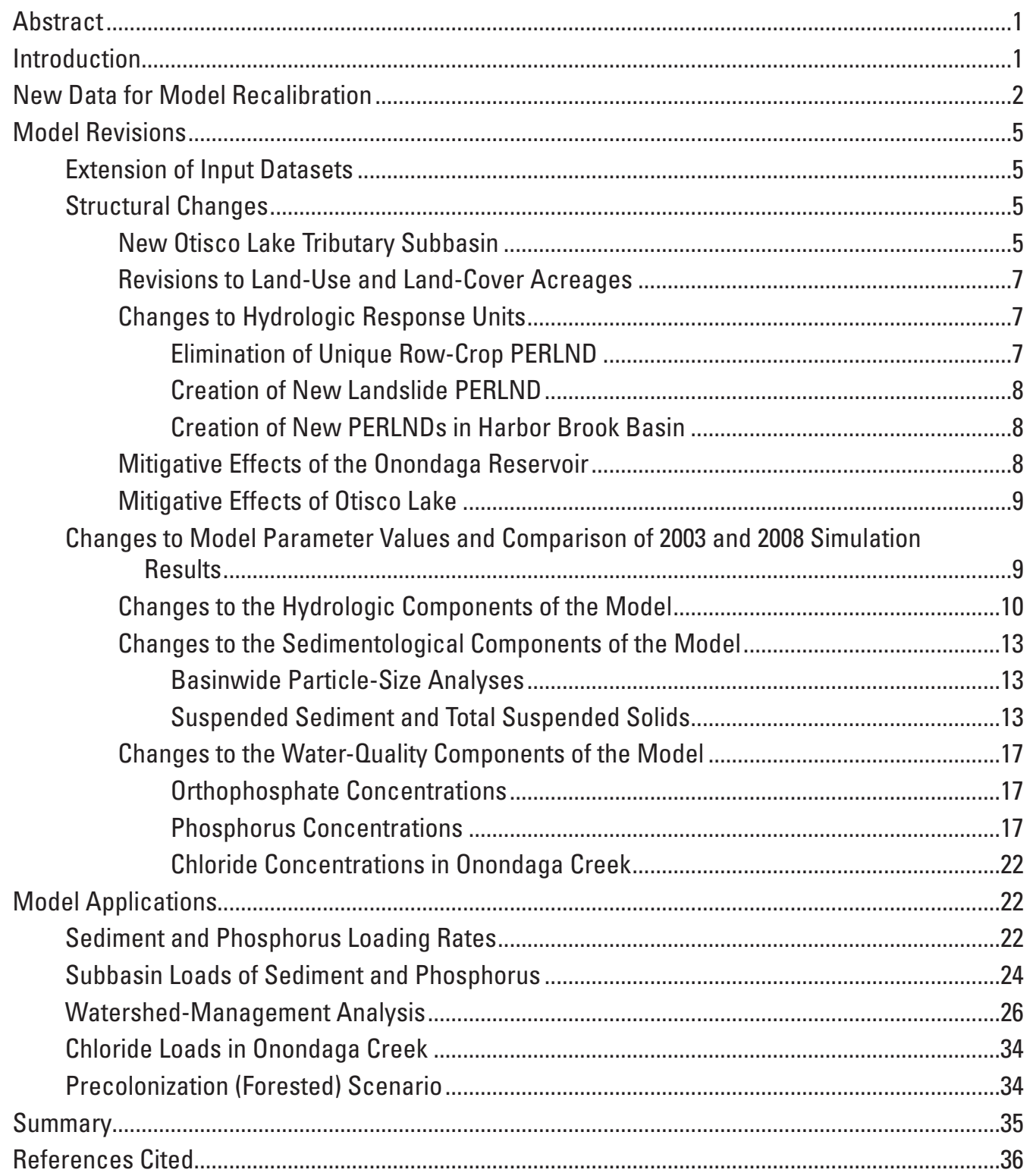




\section{Figures}

1. Map showing locations of streamflow- and water-quality-monitoring sites in the Onondaga Lake Basin, Onondaga County, New York, 2005-08.

2. Map showing subbasins and major hydrologic subdivisions used in the 2008 version of the precipitation-runoff model of the Onondaga Lake Basin, Onondaga County, New York.

3. Graphs showing streamflows simulated by the 2003 and 2008 versions of the Onondaga Lake Basin model, Onondaga County, New York, for selected headwater subbasins, 2005-08: $A$, Onondaga Creek (reach 102), $B$, Rattlesnake Gulf (reach 109), $C$, North Branch Ley Creek (reach 302), D, South Branch Ley Creek (reach 304), and E, Willow Brook (reach 405)...

4. Graphs showing streamflows simulated by the 2003 and 2008 versions of the Onondaga Lake Basin model, Onondaga County, New York, at the mouths of major tributaries to the lake, 2005-08: $A$, Onondaga Creek (reach 137), B, Harbor Brook (reach 206), C, Ley Creek (reach 312), and D, Ninemile Creek (reach 443)

5. Graphs showing flow-duration curves simulated by the 2003 and 2008 versions of the Onondaga Lake Basin model, Onondaga County, New York, at the mouths of major tributaries to the lake: $A$, Onondaga Creek (reach 137), B, Harbor Brook (reach 206), $C$, Ley Creek (reach 312), and $D$, Ninemile Creek (reach 443).

6. Graph showing paired concentrations of total suspended solids and suspended sediment in water samples collected in Onondaga Lake Basin, Onondaga County, New York, 2005-08.

7. Graphs showing suspended-sediment concentrations simulated by the 2003 and 2008 versions of the Onondaga Lake Basin model, Onondaga County, New York, for selected headwater subbasins, 2005-08: $A$, Onondaga Creek (reach 102), $B$, Rattlesnake Gulf (reach 109), C, North Branch Ley Creek (reach 302), D, South Branch Ley Creek (reach 304), and E, Willow Brook (reach 405).

8. Graphs showing suspended-sediment concentrations simulated by the 2003 and 2008 versions of the Onondaga Lake Basin model, Onondaga County, New York, at the mouths of major tributaries to the lake, 2005-08: A, Onondaga Creek (reach 137), $B$, Harbor Brook (reach 206), C, Ley Creek (reach 312), and D, Ninemile Creek (reach 443)

9. Graphs showing concentrations of orthophosphate, as phosphorus (P), simulated by the 2003 and 2008 versions of the Onondaga Lake Basin model, Onondaga County, New York, for selected headwater subbasins, 2005-08: $A$, Onondaga Creek (reach 102), B, Rattlesnake Gulf (reach 109), C, North Branch Ley Creek (reach 302), D, South Branch Ley Creek (reach 304), and E, Willow Brook (reach 405).

10. Graphs showing concentrations of orthophosphate, as phosphorus $(\mathrm{P})$, simulated by the 2003 and 2008 versions of the Onondaga Lake Basin model, Onondaga County, New York, at the mouths of major tributaries to the lake, 2005-08: $A$, Onondaga Creek (reach 137), B, Harbor Brook (reach 206), C, Ley Creek (reach 312), and D, Ninemile Creek (reach 443)...

11. Graphs showing phosphorus concentrations simulated by the 2003 and 2008 versions of the Onondaga Lake Basin model, Onondaga County, New York, for selected headwater subbasins, 2005-08: $A$, Onondaga Creek (reach 102), $B$, Rattlesnake Gulf (reach 109), C, North Branch Ley Creek (reach 302), D, South Branch Ley Creek (reach 304), and E, Willow Brook (reach 405)... 
12. Graphs showing phosphorus concentrations simulated by the 2003 and 2008 versions of the Onondaga Lake Basin model, Onondaga County, New York, at the mouths of major tributaries to the lake, 2005-08: $A$, Onondaga Creek (reach 137), $B$, Harbor Brook (reach 206), C, Ley Creek (reach 312), and D, Ninemile Creek (reach 443)

13. Graphs showing observed and simulated chloride concentrations along Onondaga Creek, Onondaga County, New York: $A$, near Cardiff (site 04237962), $B$, at Dorwin Avenue (site 04239000), $C$, at Spencer Street (site 04240010), and D, at Kirkpatrick Street (site 04240011)

14. Graph showing average annual yields of suspended sediment from subbasins simulated by the precipitation-runoff model of Onondaga Lake Basin, Onondaga County, New York

15. Graphs showing average annual yields of $A$, orthophosphate, as phosphorus (P), and $B$, phosphorus from subbasins simulated by the precipitation-runoff model of Onondaga Lake Basin, Onondaga County, New York

16. Maps showing orthophosphate, as phosphorus (P), $A$, average annual subbasin yields and $B$, estimated subbasin yields that enter Onondaga Lake, Onondaga County, New York

17. Maps showing phosphorus $A$, average annual subbasin yields and $B$, estimated subbasin yields that enter Onondaga Lake, Onondaga County, New York.

18. Graph showing annual chloride loads simulated at four sites along Onondaga Creek by the precipitation-runoff model of Onondaga Lake Basin, Onondaga County, New York

\section{Tables}

1. Streamflow- and water-quality-monitoring sites in the Onondaga Lake Basin, Onondaga County, New York, 2005-08.

2. Estimated removal efficiencies for selected constituents for the Onondaga Reservoir on Onondaga Creek, Onondaga County, New York, 2006-08.

3. Selected headwater subbasins for comparison of output from the 2003 and 2008 versions of the Onondaga Lake Basin models, Onondaga County, New York.....

4. Model-performance statistics for 1997-2003 streamflows simulated by the 2008 version of the Onondaga Lake Basin model, Onondaga County, New York, at the mouths of major tributaries to the lake.

5. Average annual sediment and phosphorus loading rates for water years 1998-2008 from pervious and impervious land types in five major subdivisions of the Onondaga Lake Basin simulated by the 2008 version of the precipitation-runoff model of the Onondaga Lake Basin, Onondaga County, New York.

6. Average annual sediment and phosphorus loading rates for water years 1998-2008 from pervious land types in five major subdivisions of the Onondaga Lake Basin simulated by the 2003 and 2008 versions of the precipitation-runoff model of the Onondaga Lake Basin, Onondaga County, New York

7. Average annual orthophosphate, as phosphorus (P), and phosphorus loads simulated in tributaries to Onondaga Lake by the precipitation-runoff model of Onondaga Lake Basin, Onondaga County, New York, under current (1998-2008) and precolonization (forested) conditions 


\section{Conversion Factors, Datum, Abbreviations, and Acronyms}

Inch/pound to SI

\begin{tabular}{|c|c|c|}
\hline Multiply & By & To obtain \\
\hline \multicolumn{3}{|c|}{ Length } \\
\hline inch (in.) & 2.54 & centimeter $(\mathrm{cm})$ \\
\hline inch (in.) & 25.4 & millimeter (mm) \\
\hline foot $(\mathrm{ft})$ & 0.3048 & $\operatorname{meter}(\mathrm{m})$ \\
\hline mile (mi) & 1.609 & kilometer $(\mathrm{km})$ \\
\hline \multicolumn{3}{|c|}{ Area } \\
\hline acre & 4,047 & square meter $\left(\mathrm{m}^{2}\right)$ \\
\hline acre & 0.4047 & hectare (ha) \\
\hline square mile $\left(\mathrm{mi}^{2}\right)$ & 259.0 & hectare (ha) \\
\hline square mile $\left(\mathrm{mi}^{2}\right)$ & 2.590 & square kilometer $\left(\mathrm{km}^{2}\right)$ \\
\hline \multicolumn{3}{|c|}{ Volume } \\
\hline gallon (gal) & 3.785 & liter $(\mathrm{L})$ \\
\hline acre-foot (acre-ft) & 1,233 & cubic meter $\left(\mathrm{m}^{3}\right)$ \\
\hline \multicolumn{3}{|c|}{ Flow rate } \\
\hline cubic foot per second $\left(\mathrm{ft}^{3} / \mathrm{s}\right)$ & 0.02832 & cubic meter per second $\left(\mathrm{m}^{3} / \mathrm{s}\right)$ \\
\hline \multicolumn{3}{|c|}{ Mass } \\
\hline pound, avoirdupois (lb) & 0.4536 & kilogram (kg) \\
\hline ton, short $(2,000 \mathrm{lb})$ & 0.9072 & megagram (Mg) \\
\hline
\end{tabular}

Concentrations of chemical constituents in water are given either in milligrams per liter (mg/L) or micrograms per liter $(\mu \mathrm{g} / \mathrm{L})$.

Vertical coordinate information is referenced to the National Geodetic Vertical Datum of 1929 (NGVD 29).

Horizontal coordinate information is referenced to the North American Datum of 1983 (NAD 83).

Elevation, as used in this report, is the distance above the vertical datum.

Water year is the 12-month period October 1 through September 30 and is designated by the calendar year in which it ends and which includes 9 of the 12 months. 


\section{List of Abbreviations and Acronyms}

\begin{tabular}{ll} 
AGWO & HSPF active-groundwater-outflow volume \\
AGWRC & HSPF active-groundwater-recession coefficient \\
AOQC & HSPF concentration of constituent in groundwater outflow \\
BMPRAC & HSPF best-management practice module \\
GIS & geographic information system \\
HRU & hydrologic response unit \\
HSPF & Hydrological Simulation Program-Fortran \\
IMPLND & HSPF impervious land segment \\
IOQC & HSPF concentration of constituent in interflow outflow \\
LOADEST & USGS Load Estimation Program \\
NEXRAD & next-generation radar \\
NLCD & National Land Cover Data \\
NWS & National Weather Service \\
NPS & nonpoint source \\
OCWA & Onondaga County Water Authority \\
OCWEP & Onondaga County Department of Water Environment Protection \\
OLP & Onondaga Lake Partnership \\
PERLND & HSPF pervious land segment \\
RCHRES & HSPF stream reach or reservoir \\
USGS & U.S. Geological Survey \\
& \\
\hline
\end{tabular}

\section{Chemical Abbreviations}

$\begin{array}{ll}\mathrm{Cl} & \text { chloride } \\ \mathrm{NH}_{3} & \text { ammonia nitrogen } \\ \mathrm{NO}_{x} & \text { nitrate-plus-nitrite nitrogen } \\ \mathrm{OP} & \text { orthophosphate, dissolved } \\ \text { OrgN } & \text { organic nitrogen } \\ \text { OrgP } & \text { organic phosphorus } \\ \mathrm{SS} & \text { suspended sediment } \\ \text { TKN } & \text { ammonia-plus-organic nitrogen (total Kjeldahl nitrogen) } \\ \mathrm{P} & \text { phosphorus } \\ \text { TSS } & \text { total suspended solids }\end{array}$


THIS PAGE INTENTIONALLY LEFT BLANK 


\title{
Improvement in Precipitation-Runoff Model Simulations by Recalibration With Basin-Specific Data, and Subsequent Model Applications, Onondaga Lake Basin, Onondaga County, New York
}

\author{
By William F. Coon
}

\section{Abstract}

Water-resource managers in Onondaga County, New York, are faced with the challenge of improving the water quality of Onondaga Lake, which has the distinction of being one of the most contaminated lakes in the United States. To assist in this endeavor, during 2003-07 the U.S. Geological Survey (USGS), in cooperation with the Onondaga Lake Partnership, developed a precipitation-runoff model of the 285-square-mile Onondaga Lake Basin with the computer program Hydrological Simulation Program-Fortran (HSPF). The model was intended to provide a tool whereby the processes responsible for the generation of loads of sediment and nutrients that are transported to Onondaga Lake could be better understood. This objective was only partly attained because data for calibration of the model were available from monitoring sites only at or near the mouths of the major tributaries to Onondaga Lake; no calibration data from headwater subbasins, where the loads originated, were available. To address this limitation and thereby decrease the uncertainty in the simulated results that were associated with headwater processes, the USGS conducted a 3-year (2005-08) basinwide study to assess the quality of surface water in the Onondaga Lake Basin. The study quantified the relative contributions of nonpoint sources associated with the major land uses and land covers in the basin and also monitored known sources and presumed sinks of sediment and nutrient loads, which previously had not been evaluated. The use of the newly acquired data to recalibrate the HSPF model resulted in improvements in the simulation of processes in the headwater subbasins, including suspended-sediment, orthophosphate, and phosphorus generation and transport.

Simulation of streamflows in small subbasins was improved by adjusting model parameter values to match base flows, storm peaks, and storm recessions more precisely than had been done with the original model. Simulated recessional and low flows were either increased or decreased as appropriate for a given stream, and simulated peak flows generally were lowered in the revised model. The use of suspended-sediment concentrations rather than concentrations of the surrogate constituent, total suspended solids, resulted in increases in the simulated low-flow sediment concentrations and, in most cases, decreases in the simulated peak-flow sediment concentrations. Simulated orthophosphate concentrations in base flows generally increased but decreased for peak flows in selected headwater subbasins in the revised model. Compared with the original model, phosphorus concentrations simulated by the revised model were comparable in forested subbasins, generally decreased in developed and wetlanddominated subbasins, and increased in agricultural subbasins. A final revision to the model was made by the addition of the simulation of chloride (salt) concentrations in the Onondaga Creek Basin to help water-resource managers better understand the relative contributions of salt from multiple sources in this particular tributary. The calibrated revised model was used to (1) compute loading rates for the various land types that were simulated in the model, (2) conduct a watershedmanagement analysis that estimated the portion of the total load that was likely to be transported to Onondaga Lake from each of the modeled subbasins, (3) compute and assess chloride loads to Onondaga Lake from the Onondaga Creek Basin, and (4) simulate precolonization (forested) conditions in the basin to estimate the probable minimum phosphorus loads to the lake.

\section{Introduction}

During 2003-07, the U.S. Geological Survey (USGS), in cooperation with the Onondaga Lake Partnership (OLP), a consortium of Federal, State, and local agencies, developed a basinwide precipitation-runoff model of the 285-square mile $\left(\mathrm{mi}^{2}\right)$ Onondaga Lake Basin, Onondaga County, New York (Coon and Reddy, 2008). The objective of the model was to assist water-resource managers in making management decisions regarding nonpoint-source (NPS) contaminant loads that were contributing to water-quality problems in Onondaga Lake; in 2010, the lake was still identified as one 
of the most contaminated lakes in the United States owing to industrial and wastewater-treatment discharges, combined storm-and-sanitary-sewer overflows, and rural and urban nonpoint sources of pollution (Effler and Hennigan, 1996; Upstate Freshwater Institute, 2010). A complementary report (Coon, 2008) provided guidance on applications of the model to create and simulate scenarios of changes in the watershed. The simulated results could be compared with those from the calibrated model representing current conditions.

The model, which simulated the period from October 1997 through September 2003, was created by using the computer program Hydrological Simulation Program-Fortran (HSPF; Bicknell and others, 2001). The Onondaga Lake Basin was divided into 107 subbasins, and within these subbasins, the land area was apportioned among 16 pervious and 3 impervious land types on the basis of land use and land cover, hydrologic soil group, and aspect. The land uses and land covers included forest, pasture hay, row crops, farmsteads (that is, livestock or dairy farms), urban or recreational grass, wetlands and ponds, low- and high-intensity residential areas, and commercial-industrial-transportation areas. Pervious and impervious components of the residential and commercialindustrial-transportation land uses were simulated separately. Precipitation data that were used as input to the model were available from three sources - the National Weather Service (NWS) (A.T. DeGaetano, Northeast Regional Climate Center, written commun., 2008), the USGS (U.S. Geological Survey, 2008), and the Onondaga County Water Authority (OCWA) (M.J. Murphy, Onondaga County Water Authority, written commun., 2008). The model simulated streamflow, water temperature, concentrations of dissolved oxygen, and concentrations and loads of sediment, orthophosphate (OP), phosphorus $(\mathrm{P})$, nitrate, ammonia, and organic nitrogen in the four major tributaries to Onondaga Lake - Onondaga Creek, Harbor Brook, Ley Creek, and Ninemile Creek (fig. 1). Additional background information on the Onondaga Lake Basin and development of the 1997-2003 version of the Onondaga Lake Basin model are presented in Coon and Reddy (2008).

The model was calibrated to flows and constituent concentrations and loads that were associated with long-term monitoring sites at or near the mouths of the major tributaries to Onondaga Lake. No streamflow or water-quality data associated with the sources of contaminants in the headwater areas of the basin were available for model calibration. Therefore, parameter values that would best reproduce the observed data at the downstream monitoring sites were estimated for the entire basin. Many assumptions regarding runoff processes and sediment- and nutrient-loading rates were made to calibrate the model. Although the model simulated observed flows and constituent loads at the mouths of the streams reasonably well, uncertainty in regard to the processes that generated flows and loads in the headwater subbasins limited the utility of the model. "Good" model results (as defined by Donigian, 2002) at the mouths of the tributaries could not have supported a claim that headwater processes were being simulated accurately.
During 2005-08, the USGS, again in cooperation with the OLP, conducted an NPS assessment study at 25 surfacewater sites in the Onondaga Lake Basin that included (1) small subbasins ranging in size from 0.09 to $12.6 \mathrm{mi}^{2}$ to characterize the load contributions from areas dominated by a single land use and (or) subbasins with previously identified water-quality problems, and (2) locations along the major streams in the basin to document changes in constituent concentrations as loads were carried downstream toward the lake (Coon and others, 2009). Flows were measured and water samples were analyzed for nutrients and suspended sediment. The newly acquired data were used to update and improve the Onondaga Lake Basin model by decreasing the uncertainty in the loadgeneration processes in the headwater areas of the basin and thereby increasing the likelihood that the model was simulating the correct results at the mouths of the tributaries for the correct reasons.

This report documents the changes in model structure and parameter values that were required to recalibrate the original version of the Onondaga Lake Basin model (with a simulation period 1997-2003) to flow and water-quality data collected during 2005-08. The report compares the results of simulations of flow and concentrations of suspended sediment (SS), OP, and P in selected head-water subbasins, as well as at the long-term monitoring sites on the major tributaries to Onondaga Lake, by the original (2003) and revised (2008) models for the period from October 1, 2005, through September 30, 2008. The report then presents several applications of the model and a scenario comparison that demonstrates the utility of the model as a water-resources management tool for the members of the OLP.

\section{New Data for Model Recalibration}

The NPS study (2005-08; Coon and others, 2009) included periodic measurements of streamflow and collection of water-quality samples at 22 surface-water sites in the basin; water-quality samples also were collected at three long-term streamflow-monitoring sites (table 1; fig. 1). Continuous flow records from nine USGS streamflow-monitoring sites (U.S. Geological Survey, 2009) and water-quality data from seven of the nine sites and two additional sites, which were operated by Onondaga County Department of Water Environment Protection (OCWEP; Antonio Deskins, Onondaga County Department of Water Environment Protection, written commun., 2008), also were available for recalibration of the model. Water-quality constituents that were analyzed for the NPS study included ammonia nitrogen $\left(\mathrm{NH}_{3}\right)$, nitrite nitrogen $\left(\mathrm{NO}_{2}\right)$, nitrate-plus-nitrite nitrogen $\left(\mathrm{NO}_{\mathrm{x}}\right)$, ammonia-plusorganic nitrogen (TKN; unfiltered and filtered), orthophosphate (OP), phosphorus (P; unfiltered and filtered), and suspended sediment (SS). Selected samples also were analyzed for total suspended solids (TSS). Measured streamflows and concentrations of SS, OP, and $\mathrm{P}$ were used to recalibrate the appropriate modules of the model. 


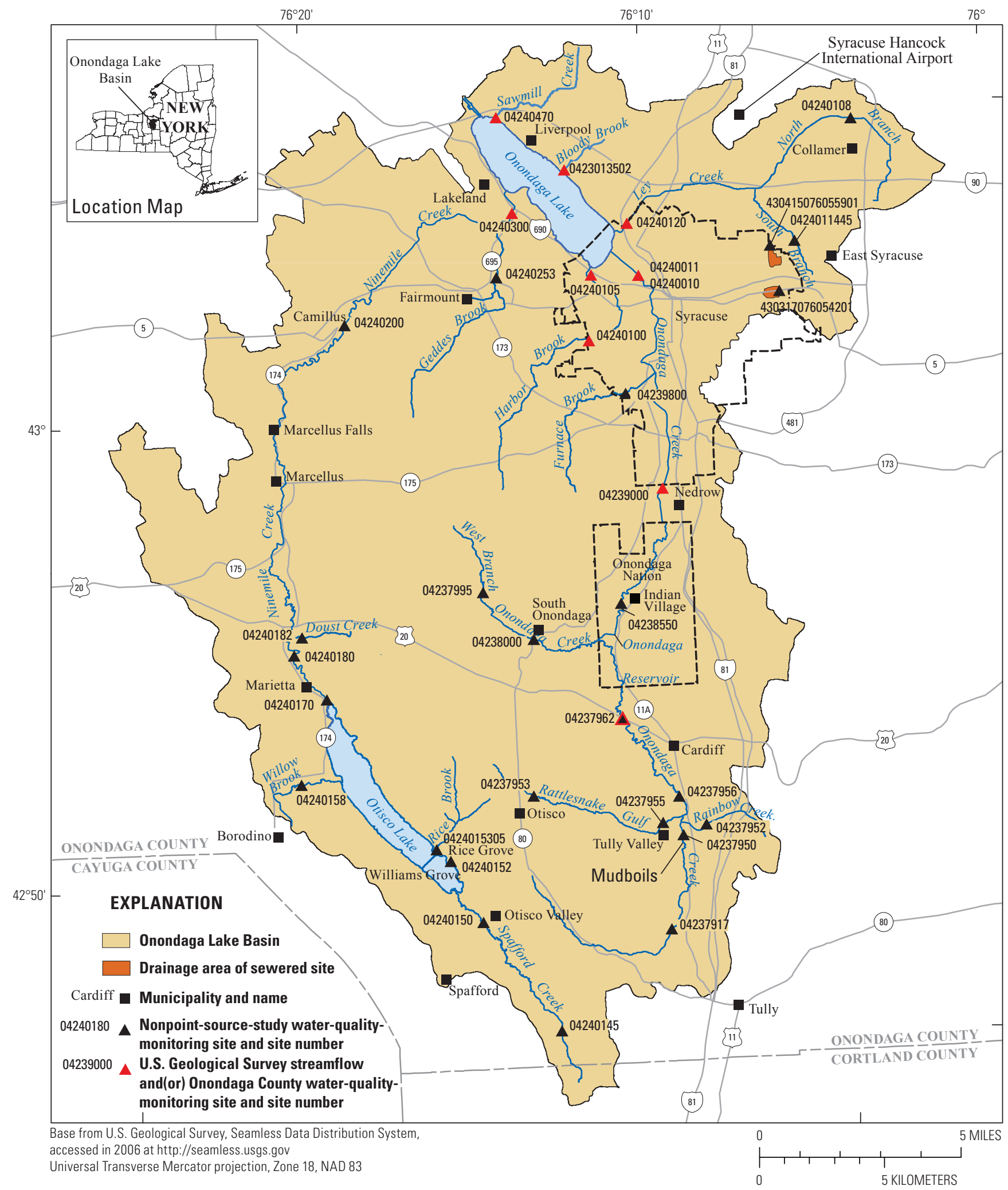

Figure 1. Locations of streamflow- and water-quality-monitoring sites in the Onondaga Lake Basin, Onondaga County, New York, 2005-08. 
Table 1. Streamflow- and water-quality-monitoring sites in the Onondaga Lake Basin, Onondaga County, New York, $2005-08$.

[Site locations are shown in figure 1. $\mathrm{mi}^{2}$, square miles; USGS, U.S. Geological Survey; OCWEP, Onondaga County Department of Water Environment Protection; Site type: NPS, periodic streamflow measurements and water-quality sampling by USGS as part of nonpoint source study, 2005-08 (Coon and others, 2009); LT, long-term streamflow monitoring by USGS and water-quality sampling by OCWEP; LT-Q + NPS-QW, long-term streamflow monitoring and periodic water-quality sampling (2005-08) by USGS; LT-QW, long-term water-quality sampling by OCWEP; --, no data]

\begin{tabular}{|c|c|c|c|c|c|c|c|}
\hline \multirow[b]{2}{*}{$\begin{array}{c}\text { Site-identification } \\
\text { number }\end{array}$} & \multirow[b]{2}{*}{ Site name and location } & \multirow[b]{2}{*}{$\begin{array}{c}\text { Drain- } \\
\text { age } \\
\text { area } \\
\left(\mathrm{mi}^{2}\right)\end{array}$} & \multirow[b]{2}{*}{$\begin{array}{l}\text { Reach } \\
\text { number }\end{array}$} & \multicolumn{4}{|c|}{ Site type } \\
\hline & & & & NPS & LT & $\begin{array}{c}\text { LT-0 } \\
+ \\
\text { NPS- } \\
\text { OW }\end{array}$ & $\begin{array}{l}\text { LT- } \\
\text { QW }\end{array}$ \\
\hline 04237917 & Onondaga Creek northwest of Tully & 6.40 & 102 & $\mathrm{X}$ & -- & -- & -- \\
\hline 04237950 & Onondaga Creek at Tully Valley & 16.4 & 106 & $\mathrm{X}$ & -- & -- & -- \\
\hline 04237953 & Rattlesnake Gulf at Otisco & 2.77 & 107 & $\mathrm{X}$ & -- & -- & -- \\
\hline 04237955 & Rattlesnake Gulf at Tully Farms Road near Cardiff & 9.06 & 109 & $\mathrm{X}$ & -- & -- & -- \\
\hline 04237956 & Onondaga Creek north of Tully Valley & 28.9 & 110 & $\mathrm{X}$ & -- & -- & -- \\
\hline 04237962 & Onondaga Creek near Cardiff & 33.9 & 111 & -- & -- & $\mathrm{X}$ & $\mathrm{X}$ \\
\hline 04239000 & Onondaga Creek at Dorwin Avenue, Syracuse ${ }^{1}$ & 88.5 & 128 & -- & $\mathrm{X}$ & -- & -- \\
\hline 04239800 & Furnace Brook at Syracuse & 3.71 & 133 & $\mathrm{X}$ & -- & -- & -- \\
\hline $04240010(04240011)$ & Onondaga Creek at Spencer Street (Kirkpatrick Street), Syracuse ${ }^{1,2}$ & 110 & 137 & -- & $\mathrm{X}$ & -- & -- \\
\hline 04240100 & Harbor Brook (above Holden Street) at Syracuse ${ }^{1}$ & 10.1 & 205 & -- & $\mathrm{X}$ & -- & -- \\
\hline 04240105 & Harbor Brook at Hiawatha Boulevard, Syracuse ${ }^{1}$ & 12.1 & 206 & -- & $\mathrm{X}$ & -- & -- \\
\hline 04240108 & North Branch Ley Creek at Collamer & 4.15 & 302 & $\mathrm{X}$ & -- & -- & -- \\
\hline 0424011445 & South Branch Ley Creek at Exeter Street at East Syracuse & 3.73 & 304 & $\mathrm{X}$ & -- & -- & -- \\
\hline 04240120 & Ley Creek at Park Street, Syracuse & 29.9 & 312 & -- & $\mathrm{X}$ & -- & -- \\
\hline 0424013502 & Bloody Brook above mouth at Liverpool & 3.86 & 501 & -- & -- & -- & $\mathrm{X}$ \\
\hline 04240170 & Otisco Lake at Marietta & 42.3 & 409 & $\mathrm{X}$ & -- & -- & -- \\
\hline 04240180 & Ninemile Creek near Marietta & 45.1 & 410 & -- & -- & $\mathrm{X}$ & -- \\
\hline 04240182 & Doust Creek near Marcellus & 1.01 & 412 & $\mathrm{X}$ & -- & -- & -- \\
\hline 04240200 & Ninemile Creek at Camillus & 84.3 & 430 & -- & -- & $\mathrm{X}$ & -- \\
\hline 04240253 & Geddes Brook at Fairmount & 8.29 & 441 & $\mathrm{X}$ & -- & -- & -- \\
\hline 04240300 & Ninemile Creek at Lakeland ${ }^{1}$ & 115 & 443 & -- & $\mathrm{X}$ & -- & -- \\
\hline 04240470 & Sawmill Creek at Liverpool & 2.34 & 502 & -- & -- & -- & $\mathrm{X}$ \\
\hline 430317076054201 & Erie Boulevard outfall to South Branch Ley Creek, Syracuse & 0.10 & 304 & $\mathrm{X}$ & -- & -- & -- \\
\hline 430415076055901 & Lamson Street outfall to South Branch Ley Creek tributary, Syracuse & 0.09 & 305 & $\mathrm{X}$ & -- & -- & -- \\
\hline
\end{tabular}

${ }^{1}$ Suspended-sediment samples were collected periodically at this site as part of the nonpoint source study (Coon and others, 2009).

${ }^{2}$ Streamflow is monitored at Spencer Street (04240010), but water-quality samples are collected at Kirkpatrick Street (04240011), 0.15 mile downstream. 


\section{Model Revisions}

A major change to the 1997-2003 version of the Onondaga Lake Basin model, hereafter referred to as the 2003 model, was the lengthening of the simulation period from an end date of September 2003 to an end date of September 2008; this change was the basis for the revised model, hereafter referred to as the 2008 model. The addition of this 5-year period necessitated the extension of all the model input files, including the meteorological datasets and known inflows and point sources of sediment and nutrients. Although the simulation period of the 2008 model was from October 1997 through September 2008, the recalibration period was only from October 2005 through September 2008, which coincided with the period of the NPS study. Calibration of the 2008 model resulted in structural and parameter-value changes to the model.

\section{Extension of Input Datasets}

Three precipitation records, one each from the National Weather Service (NWS) station north of Syracuse, N.Y., at the Syracuse Hancock International Airport, a USGS station near Tully Valley in the upper part of the Onondaga Creek Basin, and an Onondaga County Water Authority (OCWA) station at the north end of Otisco Lake (fig. 2), were used in the 2003 model. These records were applied to three areas of the Onondaga Lake Basin as approximately defined by Thiessen (1911) polygons. The precipitation records from the NWS, USGS, and OCWA stations were targeted to areas B and C, area $\mathrm{A}$, and areas $\mathrm{D}$ and $\mathrm{E}$, respectively, as shown in figure 2 . The NWS station at the Hancock Airport also provided hourly time series of air temperature, dew-point temperature, wind speed, and percentage of cloud cover. Time series of solar radiation and potential evapotranspiration were computed from the NWS-furnished data. These additional meteorological datasets were applied to the entire Onondaga Lake Basin. All the meteorological-data time series were extended to the end of the new simulation period, September 30, 2008.

Time series of daily precipitation from Next-Generation Radar (NEXRAD) data (DeGaetano and Wilks, 2008) were obtained through the Northeast Regional Climate Center (A.T. DeGaetano, Northeast Regional Climate Center, Ithaca, N.Y., written commun., 2008). Because these data were unavailable prior to January 1, 2005, and therefore did not span the entire simulation period, the data were not incorporated into the model. Instead, the NEXRAD data were used to fill in periods of erroneous or questionable data that resulted from periodic equipment malfunction at the Tully Valley rain gage. The NEXRAD data were substituted for the rain-gage data from January 2005 through April 2006 and from April through September 2008 at this site.

Other time series of input data were extended and added to the model. Daily sediment loads from mudboils, volcanolike cones of fine sand and silt, near Tully Valley, N.Y., in the upper Onondaga Creek Basin (fig. 1; Kappel and McPherson, 1998; Kappel, 2009) were computed from daily streamflows and weekly sediment concentrations with the USGS Load Estimation (LOADEST) program (Runkel and others, 2004). Because the sediment from the mudboils is derived from groundwater under confined conditions moving upward through a dense layer of silt and clay, fluctuations in loads result from the opening of new or the clogging of old mudboil vents rather than from surface runoff and erosional processes. Bias in the sediment-load estimates was minimized by using the minimum-variance unbiased estimator in the maximumlikelihood estimation method (Cohn, 1988; Cohn and others, 1992).

Hourly loads of $\mathrm{P}, \mathrm{TKN}, \mathrm{NH}_{3}$, and organic nitrogen (OrgN) from the Village of Marcellus, N.Y., wastewatertreatment plant in the Ninemile Creek Basin were estimated from once-monthly instantaneous flows and constituent concentrations (Greg Crysler, Marcellus wastewater-treatment plant operator, written commun., 2008) that were assumed to be representative of flows and concentrations for a given month. Discharges documented by seasonal measurements from springs in the carbonate-rock aquifers of the Onondaga and Bertie Limestone to Onondaga Creek in the southern part of the city of Syracuse and Ninemile Creek near Marcellus Falls (fig. 1) were used to correct discrepancies in base flows measured at the monitoring sites downstream from the springs. These discrepancies in base flows arose because the springs, a localized source of water, were not accurately simulated by the groundwater-discharge processes for the pervious land types in the model.

\section{Structural Changes}

Structural changes were made to the model by the subdivision of an existing subbasin and by revisions to the areas of specific land types in selected subbasins to reflect updated land-use and land-cover data. Changes to hydrologic response units (HRUs) were required. An existing HRU (row crops in lacustrine silt-and-clay soils) was removed from the model, and new HRUs to simulate large sediment loads from landslides and temporal changes in orthophosphate loads in the Harbor Brook Basin were added. Finally, the water-quality effects of Onondaga Reservoir at the confluence of Onondaga Creek and West Branch Onondaga Creek were incorporated into the model. The mitigative effects of Otisco Lake on water quality were also evaluated, but no structural changes to the model were required to simulate these effects.

\section{New Otisco Lake Tributary Subbasin}

A small 0.56- $\mathrm{mi}^{2}$ subbasin of the Otisco Lake Basin was included in the 2005-08 NPS study. To permit direct calibration of the effects of a farmstead, which dominated the water-quality characteristics of this subbasin, the subbasin was delineated, assigned a unique subbasin number (499; fig. 2), 


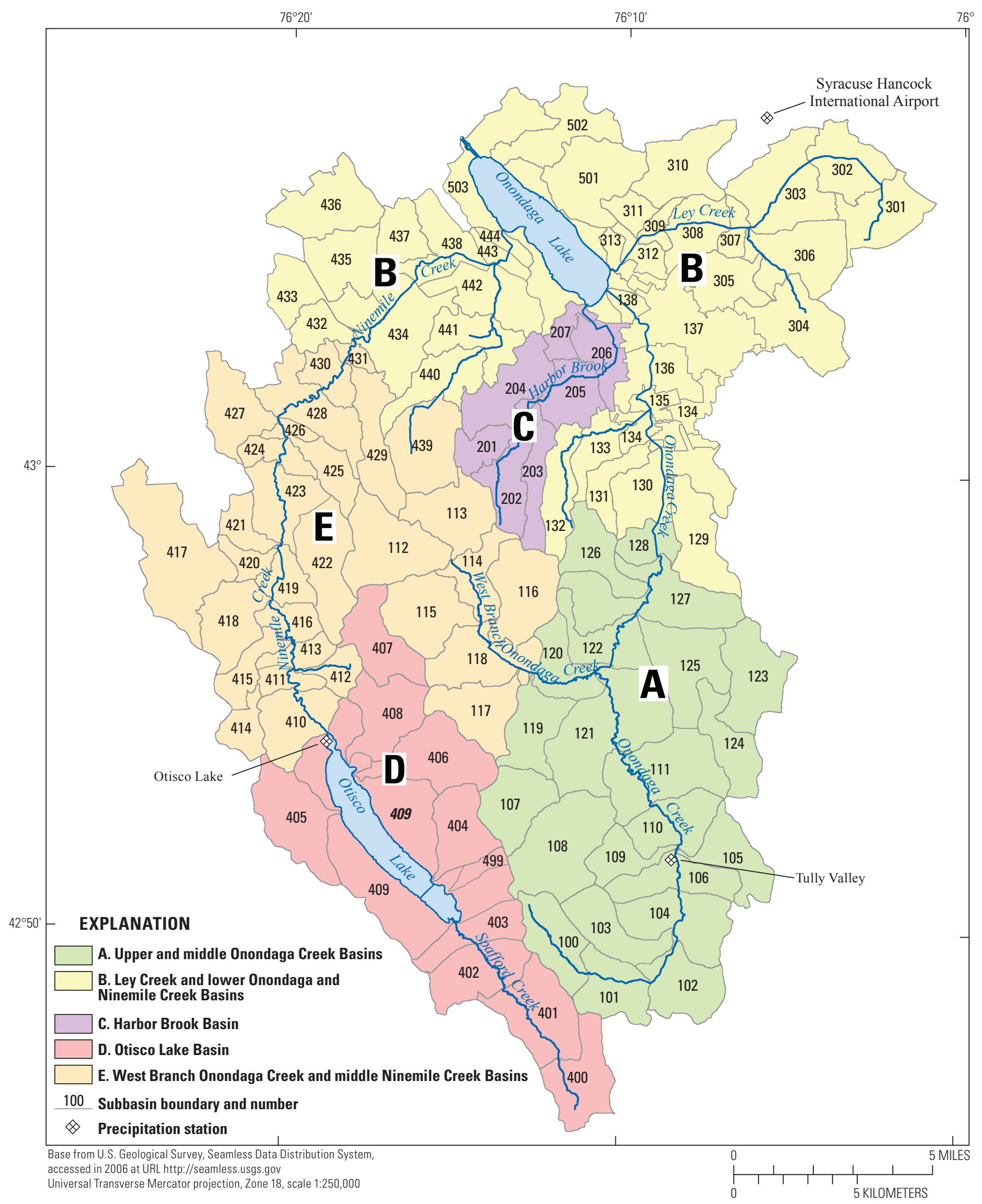

Figure 2. Subbasins and major hydrologic subdivisions used in the 2008 version of the precipitation-runoff model of the Onondaga Lake Basin, Onondaga County, New York. 
and incorporated into the model. The parameter values that were selected to calibrate sediment and nutrient concentrations measured in this subbasin - Otisco Lake tributary at Williams Grove (station number 04240152; fig. 1) - were used to simulate farmstead land types elsewhere in the Onondaga Lake Basin.

\section{Revisions to Land-Use and Land-Cover Acreages}

Land uses and land covers classified by the 1992 and 2001 National Land Cover Data datasets (NLCD; U.S. Geological Survey, 1999, 2005) were both available during the development of the 2003 model (Coon and Reddy, 2008), but only the 1992 NLCD were used because the 2001 NLCD had not been finalized at the time. The 2001 NLCD were reviewed during calibration of the 2008 model to identify any substantial changes in land uses between 1992 and 2001. Direct comparison of the two datasets was hindered because land types were defined differently in 2001 than in 1992. Nevertheless, comparisons showed that land types for almost 96 percent of the basin remained unchanged between 1992 and 2001.

The two largest differences in land use from 1992 to 2001 were the apparent conversion of agricultural land to wetlands (1,946 acres) and forest (4,201 acres); however, these results more likely reflected misclassification of land types by one of the surveys rather than real changes in land types. For instance, wetlands that were erroneously classified as row crops in the 1992 NLCD (Coon and Reddy, 2008) were correctly identified in the 2001 NLCD, which incorporated freshwater wetlands regulated by the New York State Department of Environmental Conservation (1999) and wetlands from the National Wetland Inventory (U.S. Fish and Wildlife Service, 2000). Wetlands from these two datasets were included in the wetland geographic information system (GIS) layer that was developed for and used to correct this land-type error in the 2003 model. Forested areas, as defined by the 2001 NLCD, are characterized by woody vegetation that is generally greater than about 20 feet (ft) (6 meters) tall, a tree height that could not be attained in 9 years on land that was formerly classified as agricultural land. For this reason, the 1992 NLCD classification was retained for HRUs where the 2001 NLCD indicated conversion of agricultural to forested land.

Although areas of row-crop and pasture-hay land in the 1992 NLCD might have changed in specific locations identified in the 2001 NLCD, the total area covered by these land uses in a given subbasin did not change substantially, and therefore the acreages associated with these land uses were not revised in the 2008 model. Areas of urban development were scrutinized to assess the extent of urban expansion, especially in the northern third of the Onondaga Lake Basin. Acreages of developed land uses were adjusted in 13 subbasins where at least 9 acres (an arbitrary size) of forested and wetland land were converted to developed land. Areas of urban developed land increased the most in the headwater subbasins of North
Branch Ley Creek (subbasins 301-303 and 310; fig. 2) and the subbasins that drain directly to Onondaga Lake (subbasins 501-503; fig. 2).

\section{Changes to Hydrologic Response Units}

Within the 2003 model of the Onondaga Lake Basin, the land area was segmented into 22 HRUs, which included 16 pervious land types (PERLNDs) and 6 impervious land types (IMPLNDs). Each PERLND (which was defined on the basis of land use or land cover, hydrologic soil group, and aspect) and each IMPLND (which was defined on the basis of land use) was assumed to show homogeneous hydrologic and water-quality responses to meteorological inputs. The data that were collected during the NPS study indicated that one PERLND that simulated row crops grown in lacustrine silt-and-clay soils was unnecessary and that a new PERLND that simulated landslide processes was required. PERLNDs to simulate high and seasonally variable concentrations of $\mathrm{OP}$ in the Harbor Brook Basin also were added to the model.

\section{Elimination of Unique Row-Crop PERLND}

Paschal and Sherwood (1987) monitored the water quality of the five main tributaries of Otisco Lake during 1981-83, estimated sediment and nutrient loads from each subbasin, and related these loads to land use, geology, and soil type. They identified a disproportionately large sediment load from Spafford Creek (subbasins 400-403; fig. 2), the largest of the five tributaries, and concluded that the source of this sediment was the lacustrine silt-and-clay soils in row-crop use in the valley bottom. Spafford Creek carried 72 percent of the total sediment load that was transported to Otisco Lake during the $1982-83$ water years; the annual yield (load per unit area) was 0.52 short ton per acre compared to 0.05 to 0.12 ton per acre for other tributaries. On the basis of this analysis, the 2003 model was set up to mimic this sediment load in the Spafford Creek subbasin as well as in other locations with similar conditions throughout the Onondaga Lake Basin. Loading rates for row-crop areas that were not in lacustrine silt-and-clay soils were calibrated to the low rates in the other Otisco Lake subbasins. A unique PERLND - row crops in lacustrine siltand-clay soils-was created for the Spafford Creek subbasin and calibrated in the 2003 model to make the final basinwide yield approximate the computed rate of 0.52 ton per acre per year. In fact, the loading rate for this PERLND was increased to more than 15 tons per acre per year, which seemed excessive and produced a basinwide yield of only 0.38 ton per acre per year. Additional increases in the loading rate for this PERLND were not pursued for the 2003 model.

During the 2005-08 NPS study (Coon and others, 2009), three of the five major tributaries to Otisco Lake, including Spafford Creek, were monitored. The results of this study indicated that although Spafford Creek still had the largest yield of suspended sediment, the yield was not 4 to 10 times larger than the yields at the other sites as the 
Improvement in Precipitation-Runoff Model Simulations by Recalibration and Model Applications, Onondaga Basin, N.Y.

data from Paschal and Sherwood (1987) seemed to indicate. Presumably agricultural-management practices in the Spafford Creek subbasin decreased sediment loads subsequent to 1983. Recalibration of the model indicated that all row-crop land uses could be simulated with a single PERLND, and that the unique PERLND - row crops in lacustrine silt-and-clay soils - was unnecessary. For this reason, the unique PERLND was removed from the model.

\section{Creation of New Landslide PERLND}

Rainbow Creek (subbasin 105, fig. 2) and Rattlesnake Gulf (subbasins 107-109, fig. 2), two tributaries to Onondaga Creek in the headwater area of that basin, are known sources of large sediment loads (Coon and others, 2009). The magnitudes of these loads, which are derived from the erosion of landslide materials within their respective basins, were undocumented prior to the 2005-08 NPS study. Model parameter values that controlled sediment processes-soil detachment, washoff, and scour - were adjusted in the 2008 model to match the suspended-sediment concentrations measured in these streams. These adjustments to parameter values for existing PERLNDs, however, failed to produce the desired results in Rainbow Creek and Rattlesnake Gulf without also adversely affecting SS concentrations simulated in other streams. Therefore, a new PERLND (no. 17) with exceptionally high values for the soil-detachment, washoff, and scour parameters was created for these two subbasins in the 2008 model. The areal extents of the landslide areas were determined by Tamulonis and others (2009).

\section{Creation of New PERLNDs in Harbor Brook Basin}

Observed OP concentrations in Harbor Brook (area C in fig. 2) were much higher near the mouth of the stream (at Hiawatha Boulevard, site 04240105) than concentrations farther upstream (above Holden Street, site 04240100; table 1; fig. 1) and in other streams in the Syracuse urban area. Also, base-flow concentrations of OP increased during the 2003-08 simulation period, which violated the modeling assumption that basin processes were relatively constant during the simulation period and made matching simulated and observed OP concentrations unlikely with a single parameter set in the 2008 model. Eighty-six percent of the Hiawatha Boulevard subbasin (no. 206, fig. 2) is classified as having developed land uses, and storm runoff from the entire subbasin flows into a combined sanitary-and-storm sewer system. Additionally, Harbor Brook flows through a tunnel for about half the distance between Holden Street and Hiawatha Boulevard (sites 04240100 and 04240105 in fig. 1). Plausible reasons for the high and gradually increasing OP concentrations were sought, but data were unavailable to support any proposed explanation.

Because HSPF, as structured for the Onondaga Lake Basin model, is designed to simulate average or representative conditions in a basin during the period of simulation, parameter values that control OP concentrations could not be adjusted to mimic the observed data. Attempts to resolve the simulation discrepancies at Hiawatha Boulevard failed because improvements in OP simulations in this subbasin resulted in degraded simulated-to-observed relations at other calibration sites. The solution to this problem was to create a new set of PERLNDs to permit simulation of high-OP contributions from pervious land in the combined sanitary-andstorm sewered areas of the Harbor Brook Basin and to add instructions to the special-actions module of HSPF to permit simulation of the increasing trend in the OP concentrations during the simulation period. These changes permitted high and seasonally variable concentrations of $\mathrm{OP}$ to be simulated at Hiawatha Boulevard without affecting the simulation results for other urban areas of the Onondaga Lake Basin.

\section{Mitigative Effects of the Onondaga Reservoir}

The Onondaga Reservoir on Onondaga Creek downstream from the confluence with West Branch Onondaga Creek (fig. 1) was constructed by the U.S. Army Corps of Engineers in 1949 to control flooding in Syracuse. This dam, which has a capacity of 18,200 acre-feet and can create an 860 -acre pool at the spillway crest elevation of $504.5 \mathrm{ft}$ (U.S. Army Corps of Engineers, 1945), controls flows from a $67.7-\mathrm{mi}^{2}$ drainage area. Although this dam is a flow-through structure with an open tunnel but without gates or any other mechanism to retain storm runoff, by design it does attenuate stormflows and temporarily detains water and, depending on water levels, disperses stormwater across the flood plain.

The two major inflows to the reservoir-Onondaga Creek near Cardiff, N.Y. (site 04237962) and West Branch Onondaga Creek at South Onondaga, N.Y. (site 04238000)_and the outflow from the reservoir - Onondaga Creek at Indian Village, N.Y. (site 04238550, table 1; fig. 1) -were monitored during the NPS study. On the basis of instantaneous loads computed from limited data collected at these three sites (Coon and others, 2009; table 2), constituent removal efficiencies that could be attributed to the combined effects of the reservoir and the low-gradient channel upstream from the reservoir were estimated. These removal efficiencies were found to be related to flow regime. For all measured constituents except $\mathrm{NH}_{3}$, the reservoir had small or no effects on constituent loads during base-flow periods; $\mathrm{NH}_{3}$ loads in base-flow outflows decreased compared to inflows. Loads of all constituents decreased during storm-runoff periods when the constriction of the tunnel caused water to back up, disperse, and deposit sediment onto the flood plain. These results were simulated in the model by splitting the inflow to the reservoir between low flows, which were routed directly to the downstream reach, and high flows, which were routed to the HSPF best-management practice module (BMPRAC). Removal fractions were calibrated to reproduce the removal efficiencies estimated from data for water years 2007-08. 
Table 2. Estimated removal efficiencies for selected constituents for the Onondaga Reservoir on Onondaga Creek, Onondaga County, New York, 2006-08.

[Removal efficiencies were computed from limited data collected during 2006-08 (Coon and others, 2009). A negative (positive) value indicates a decrease (increase) in the constituent loads from inflow to outflow]

\begin{tabular}{lccc}
\hline \multirow{1}{*}{\multicolumn{1}{c}{ Constituent }} & \multicolumn{3}{c}{$\begin{array}{c}\text { Estimated removal efficiency, } \\
\text { in percent }\end{array}$} \\
\cline { 2 - 4 } & Base flow & Stormflow & All flows \\
\hline Ammonia nitrogen & -33 & -52 & -50 \\
Ammonia-plus-organic nitrogen & 13 & -65 & -62 \\
Nitrate-plus-nitrite nitrogen & 15 & -38 & -32 \\
Orthophosphate & 3 & -54 & -52 \\
Phosphorus & 25 & -64 & -63 \\
Suspended sediment & 1 & -39 & -39 \\
\hline
\end{tabular}

\section{Mitigative Effects of Otisco Lake}

Otisco Lake, with a surface area of $2.93 \mathrm{mi}^{2}$ and an average depth of $33.5 \mathrm{ft}$, holds 21 billion gallons of water at its mean elevation of $788 \mathrm{ft}$ (Bloomfield, 1978). The large volume and relatively long detention time of the lake mitigate the loads of sediment and nutrients that enter the lake. This mitigative effect was assessed by comparing data collected during the NPS study (2005-08) for inflows from three of the major tributaries to the lake- Spafford Creek at site 04240150, Rice Brook at site 0424015305, and Willow Brook at site 04240158 (fig. 1; table 1), which collectively drain 43 percent of the Otisco Lake Basin - with data for outflow from the lake at Marietta, N.Y., site 04240170 (fig. 1; table 1; Coon and others, 2009).

Outflows, which are regulated by the dam at the north end of the lake, do not reflect time-specific hydrologic and waterquality processes in the Otisco Lake Basin. In other words, the magnitude and quality of the lake's outflow are not related to the magnitude and quality of concurrent flows entering the lake because of the storage and mixing characteristics of the lake. For this reason and because flow data were unavailable to compute loads, median concentrations of nutrients and SS were compared between inflows and outflow to assess the lake's mitigative effects on these constituents (Coon and others, 2009). The concentrations in Otisco Lake outflow were much lower than in the inflows for all constituents, except $\mathrm{NH}_{3}$, for which concentrations were similar in magnitude. Median outflow concentrations of TKN, $\mathrm{NO}_{x}$, and OP were 65,83 , and 85 percent lower than the respective averages of the median concentrations in inflows from the three monitored tributaries to the lake. The most striking differences were for $\mathrm{P}$ and SS, for which median outflow concentrations were only 9 and 4 percent, respectively, of the average of the three inflow median concentrations.
For the 2003 model, water-quality loads in Otisco Lake outflow were computed from average summertime epilimnion concentrations (Callinan, 2001; C.W. Callinan, New York State Department of Environmental Conservation, written commun., 2004) and daily lake outflows (M.J. Murphy, Onondaga County Water Authority, written commun., 2004), and were input to the receiving stream reach (RCHRES) as point sources of constituent loads (Coon and Reddy, 2008). Calibration of the 2008 model was achieved by simulating Otisco Lake as a flow-through RCHRES; that is, outflow constituents were routed directly from the lake to the downstream reach. Neither input of constituent loads as point sources nor simulation of constituent removals by a BMPRAC, as was done with Onondaga Reservoir, were necessary. The simulated loads of $\mathrm{P}$ and $\mathrm{OP}$ in the outflow from Otisco Lake were 14 and 12 percent, respectively, of the combined inflow loads to the lake, which included the simulated loads from the five major tributaries and the estimated loads from the areas that drain directly to the lake.

\section{Changes to Model Parameter Values and Comparison of 2003 and 2008 Simulation Results}

Model parameter values were changed on the basis of recalibration of simulated flows and concentrations and loads of sediment and nutrients on the basis of instantaneous measured flows, daily streamflows (where available), and all chemical-concentration data that were collected during 200508 at the 25 NPS sites (Coon and others, 2009). In addition, continuous flow records from nine USGS streamgages (U.S. Geological Survey, 2009) and water-quality data from seven colocated and two additional water-quality monitoring sites, which were operated by the OCWEP (Antonio Deskins, Onondaga County Department of Water Environment Protection, written commun., 2008), also were available for recalibration of the model. All data from these latter sites, including the 1997-2003 data that had been used to calibrate the 2003 model, as well as new data that had been collected during 2003-08, were used to calibrate the 2008 model.

The results from simulations by the 2003 and 2008 versions of the model were compared for the period October 1, 2005 through September 30, 2008. Five reaches that represent subbasins dominated by a particular land type were selected to compare results for the headwater areas of the basin; the names of the streams, reach and subbasin numbers, monitoring-site identification numbers, and the dominant land types in the subbasins are listed in table 3 . In addition, the results for the four long-term monitoring sites near the mouths of the major tributaries to Onondaga Lake - Onondaga Creek (site 04240010), Harbor Brook (site 04240105), Ley Creek (site 04240120), and Ninemile Creek (site 04240300; fig. 1; table 1)-were also compared to assess changes in simulated flows and constituent concentrations as a result of model recalibration. 
Table 3. Selected headwater subbasins for comparison of output from the 2003 and 2008 versions of the Onondaga Lake Basin models, Onondaga County, New York.

[Values in parentheses under "Dominant land types" are percentages of the total area in each subbasin]

\begin{tabular}{lcccc}
\hline \multicolumn{1}{c}{ Stream } & $\begin{array}{c}\text { Model-reach } \\
\text { subbasin } \\
\text { number }\end{array}$ & $\begin{array}{c}\text { Monitoring-site } \\
\text { identification } \\
\text { number }\end{array}$ & $\begin{array}{c}\text { Drainage area, } \\
\text { in square } \\
\text { miles }\end{array}$ & \multicolumn{1}{c}{ Dominant land types } \\
\hline $\begin{array}{l}\text { Onondaga Creek } \\
\text { Rattlesnake Gulf }\end{array}$ & 102 & 04237917 & 6.40 & $\begin{array}{c}\text { Forest (62) and agriculture (33). } \\
\text { Forest (47) and agriculture (47), but water quality is } \\
\text { dominated by erosion of landslide materials. } \\
\text { North Branch Ley Creek }\end{array}$ \\
109 & 04237955 & 9.06 & 4.15 & $\begin{array}{c}\text { Mixed uses: forest (37), agriculture (25), and developed } \\
\text { (10), but water quality is dominated by wetland (27). }\end{array}$ \\
South Branch Ley Creek & 302 & 04240108 & 3.73 & $\begin{array}{c}\text { Residential (47) and commercial, industrial, and } \\
\text { transportation (27). }\end{array}$ \\
Willow Brook & 304 & 0424011445 & 1.95 & Agriculture (79). \\
\hline
\end{tabular}

\section{Changes to the Hydrologic Components of the Model}

Changes made to parameter values controlling hydrologic components from the 2003 to the 2008 model had noticeable effects on the simulated hydrographs of streams in the small headwater subbasins (fig. 3). The active-groundwaterrecession coefficient (AGWRC) controls the rate at which groundwater discharges to streams. On the basis of flow data recorded on South Branch Ley Creek (fig. 3D) and Geddes Brook (model results not shown), the values of AGWRC were decreased for the developed HRUs in these subbasins in the 2008 model. Conversely, in the Harbor Brook Basin, the AGWRC values for residential and commercialindustrial-transportation uses were increased slightly. The groundwater-outflow modifier (KVARY) was adjusted by land type in the 2008 model rather than by the major hydrologic subdivisions that were defined by precipitation records (fig. 2) in the 2003 model. On the basis of simulation results for the agriculture-dominated Willow Brook Basin, the lower-zone evapotranspiration value (LZETP) was increased for row crops during the summer months in the 2008 model (see fig. 3E). The timing and magnitude of wintertime peak flows were improved by lowering the wet-bulb air temperature, below which precipitation occurs as snow under saturated conditions (TSNOW).

On the basis of flow data recorded on North Branch Ley Creek (fig. 3C), which drains a low-gradient area of which 27 percent is covered by wetlands, the length of the assumed overland flow plane was increased and the slope of the overland flow plane was decreased to delay the response time to overland runoff. To decrease summer flows, water losses due to evapotranspiration were increased by doubling the potential evapotranspiration associated with wetlands and increasing the values for evapotranspiration from active groundwater storage (AGWETP). This adjustment was considered reasonable given that (1) potential evapotranspiration was computed by the Hamon (1961) method, which is solely a function of daily mean air temperature and the number of possible hours of sunshine, and makes no allowance for different vegetation types, and (2) wetland vegetation, such as cattails, have an unlimited supply of water and a large ratio of leaf-surface area to land area, which would maximize transpiration rates.

As a result of these revisions, simulated recessional and low flows were either increased or decreased as appropriate for a given stream. Of the five headwater sites selected for comparison (table 3), peak flows simulated by the 2008 model generally were lower than those simulated by the 2003 model (fig. 3); only the peak flows for Willow Brook (fig. 3E) were consistently higher with the 2008 model than with the 2003 model.

At the calibration sites near the mouths of the major tributaries to Onondaga Lake, the effects of the hydrologic revisions to the model were mixed (fig. 4). In most instances for these downstream sites, the simulated flows from the two versions of the model were reasonably close. This outcome was not unexpected, because streamflow data were available and used to calibrate flows at these sites in both versions of the model. Nevertheless, differences in simulated low flows were noticeable for Onondaga Creek (fig. 4A), Harbor Brook (fig. 4B), and Ninemile Creek (fig. 4D). Peak flows in Harbor Brook simulated by the 2008 model generally decreased, whereas those in Ninemile Creek generally increased. Simulated peak flows in Onondaga Creek either decreased or increased; whereas those in Ley Creek (fig. 4C) were essentially unchanged from those simulated by the 

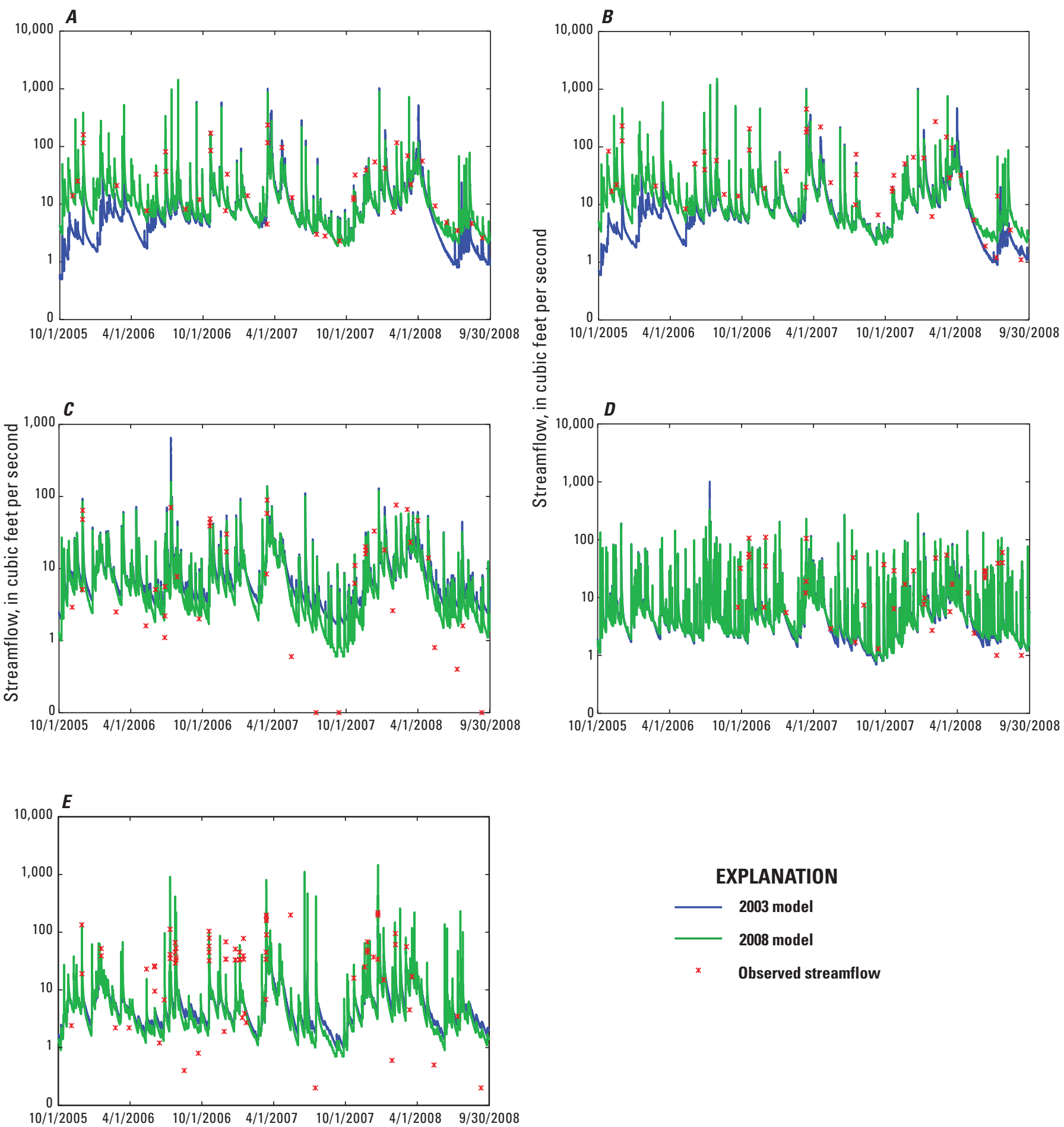

Figure 3. Streamflows simulated by the 2003 and 2008 versions of the Onondaga Lake Basin model, Onondaga County, New York, for selected headwater subbasins, 2005-08: A, Onondaga Creek (reach 102), B, Rattlesnake Gulf (reach 109), C, North Branch Ley Creek (reach 302), D, South Branch Ley Creek (reach 304), and E, Willow Brook (reach 405). 

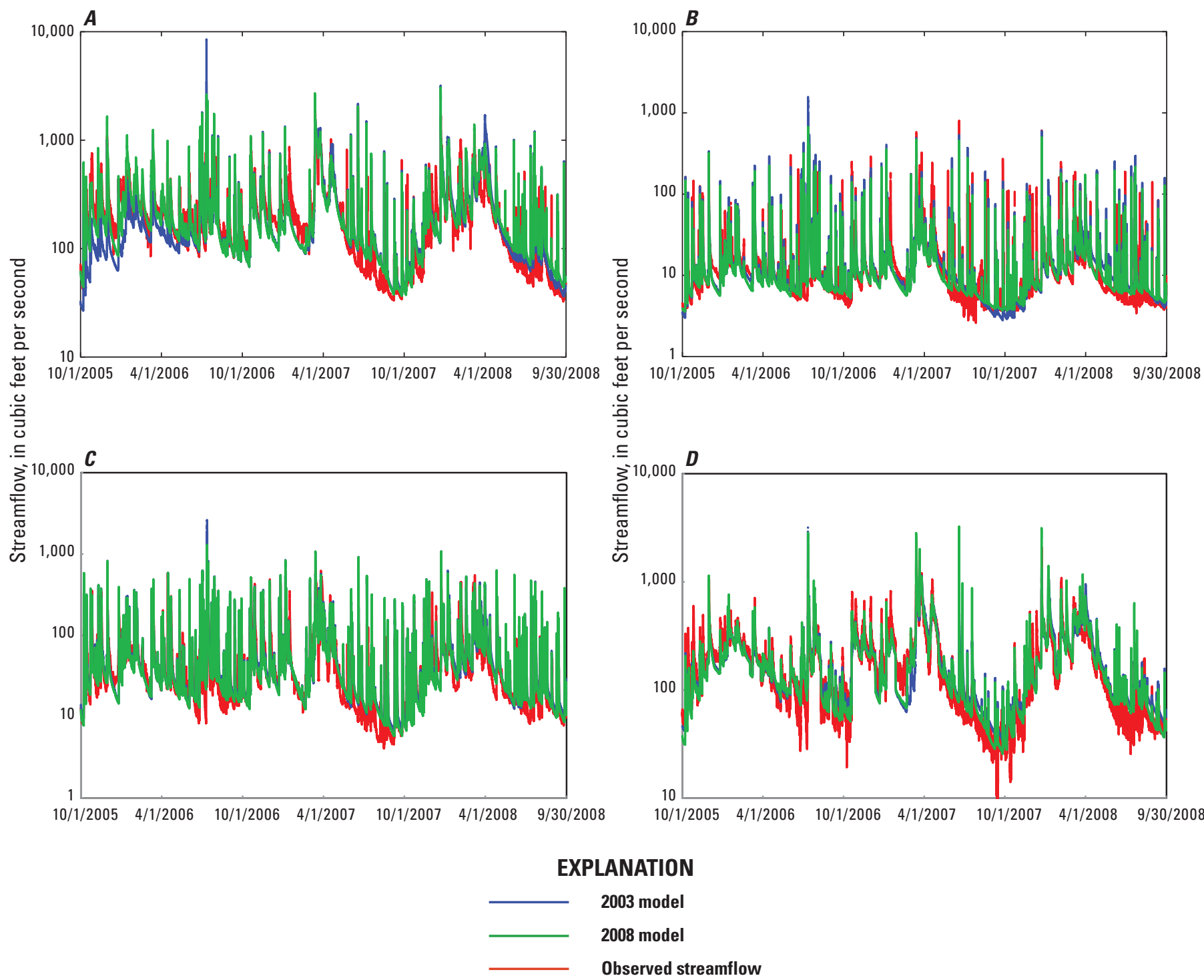

Figure 4. Streamflows simulated by the 2003 and 2008 versions of the Onondaga Lake Basin model, Onondaga County, New York, at the mouths of major tributaries to the lake, 2005-08: A, Onondaga Creek (reach 137), B, Harbor Brook (reach 206), $C$, Ley Creek (reach 312), and $D$, Ninemile Creek (reach 443). 
2003 model. Despite these discrepancies, agreement and even overall improvement in streamflow simulations by the 2008 model compared to those generated by the 2003 model were noted. For example, the flow durations computed by the 2003 model for the 1997-2003 simulation period and by the 2008 model for the 1997-2008 period were both close to the respective flow durations of observed daily streamflows (fig. 5). In addition, model-performance statistics (table 4) indicated that the 2008 model simulated daily and monthly mean streamflows at the mouths of at least three of the four major tributaries to Onondaga Lake with less bias, higher correlation, and better model fit than did the 2003 model. Daily streamflows in Ninemile Creek at Lakeland were not simulated as well by the 2008 model as were done by the 2003 model; however, simulated monthly streamflows were slightly improved by the revisions to the 2008 model.

\section{Changes to the Sedimentological Components of the Model}

Particle-size analyses that were performed on SS samples collected during the NPS study (Coon and others, 2009) enabled refinement of the proportions of the simulated sediment load into its three components - sand, silt, and clay. In addition, comparison of SS and TSS concentrations in concurrently collected water samples documented that TSS concentrations were poor calibration surrogates for SS concentrations simulated by the 2003 model. This comparison justified major revisions to the sedimentological components of the 2008 model.

\section{Basinwide Particle-Size Analyses}

Particle-size analyses of SS in water samples collected by Paschal and Sherwood (1987) from Otisco Lake tributaries during 1981-83 indicated a sediment composition that, on average, was 10 percent sand, 55 percent silt, and 35 percent clay. In the absence of other data from the Onondaga Lake Basin, these percentages were used to apportion sediment loads from PERLNDs and IMPLNDs to the receiving RCHRESs in the 2003 model. During 2005-08, particle sizes were analyzed in storm samples of SS that were collected from 18 sites throughout the Onondaga Lake Basin as part of the NPS study (Coon and others, 2009). The data confirmed an approximate 10- to 90-percent split between sand and siltplus-clay (fines) in water samples collected from Otisco Lake tributaries as well as from other sites but showed that these percentages were not applicable across the entire Onondaga Lake Basin. Some samples had sand-fine splits as high as 40 to 60 percent. Therefore, three combinations of sediment proportions were used in the 2008 model - the original lowsand-percentage composition (10,55, and 35 percent sand, silt, and clay, respectively), a high-sand-percentage composition (40, 35, and 25 percent sand, silt, and clay, respectively), and an average composition (23, 47, and 30 percent sand, silt, and clay, respectively). Lacking the percentages of silt and clay in the fines fraction of the 2005-08 particle-size analyses, the relative percentages of silt and clay in the 1981-83 analyses were used to estimate the silt and clay fractions in the 2005-08 samples. The low- and high-sand compositions were applied to the PERLNDs in the basins from which the particle-size data were collected. The average values were applied to PERLNDs in all other basins, as well as to all IMPLNDs.

\section{Suspended Sediment and Total Suspended Solids}

Except for data available from the 1981-83 study of the tributaries to Otisco Lake by Paschal and Sherwood (1987), no sediment-concentration or load data were available to calibrate the 2003 model. TSS data were used as a surrogate constituent, but comparison of TSS and SS concentrations in samples that were collected during the 2005-08 NPS study (Coon and others, 2009) indicated a large negative bias in the TSS concentrations - that is, TSS concentrations usually were less than SS concentrations (fig. 6). Therefore, major changes to the simulated land-segment and instream processes related to transport, deposition, and scour of the suspended fractions of sand, silt, and clay were required to calibrate the 2008 model.

The first major revision to the model to mimic observed SS concentrations was the simulation of a base-flow load. HSPF simulates SS loads primarily as a storm-related process; that is, sediment loads are derived from the detachment and washoff of soil from land surfaces during rainfall events. Channel scour can be simulated, but this process is controlled by the mean flow velocity in a given RCHRES. Therefore, during base flows, no sediment inputs from land surfaces are simulated, and channel scour commonly is near zero. Contrary to these modeling limitations, the NPS study documented that SS concentrations were sustained in base flows at higher levels than could be simulated by the HSPF algorithms (fig. 7). To rectify this shortcoming, a base load of sediment was tied to the groundwater outflow volume (AGWO) from pervious land segments. Because AGWO is a constant source of water to streams, tying sediment inputs to AGWO ensured a constant supply of sediment to base flows. Different multiplication factors were used to target these sediment inputs to the silt and clay components of the SS input loads to each RCHRES.

One subbasin, Rattlesnake Gulf (subbasin no. 109; fig. 2), has a continuous and elevated base-flow SS load, which is derived from unstable lacustrine silt and clay deposits that periodically slump from the steep valley side into the channel along a high-gradient reach of the stream (Tamulonis and others, 2009). To increase the simulated base-flow SS concentrations to the observed levels in this stream, constant loads of silt and clay sediment fractions (in addition to the AGWO-associated inputs) were added to the modeled reach through the HSPF external sources module; the results of this step are shown in figure 7B. Simulated peak SS concentrations were calibrated to observed concentrations by adjusting the model parameters that control soil detachment and sediment washoff and scour during periods of storm runoff. In the case of Rattlesnake Gulf, the creation of a unique PERLND (see 
2003 MODEL

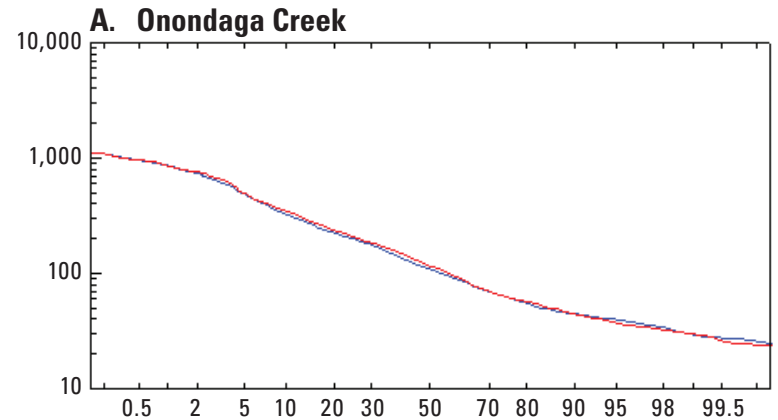

B. Harbor Brook
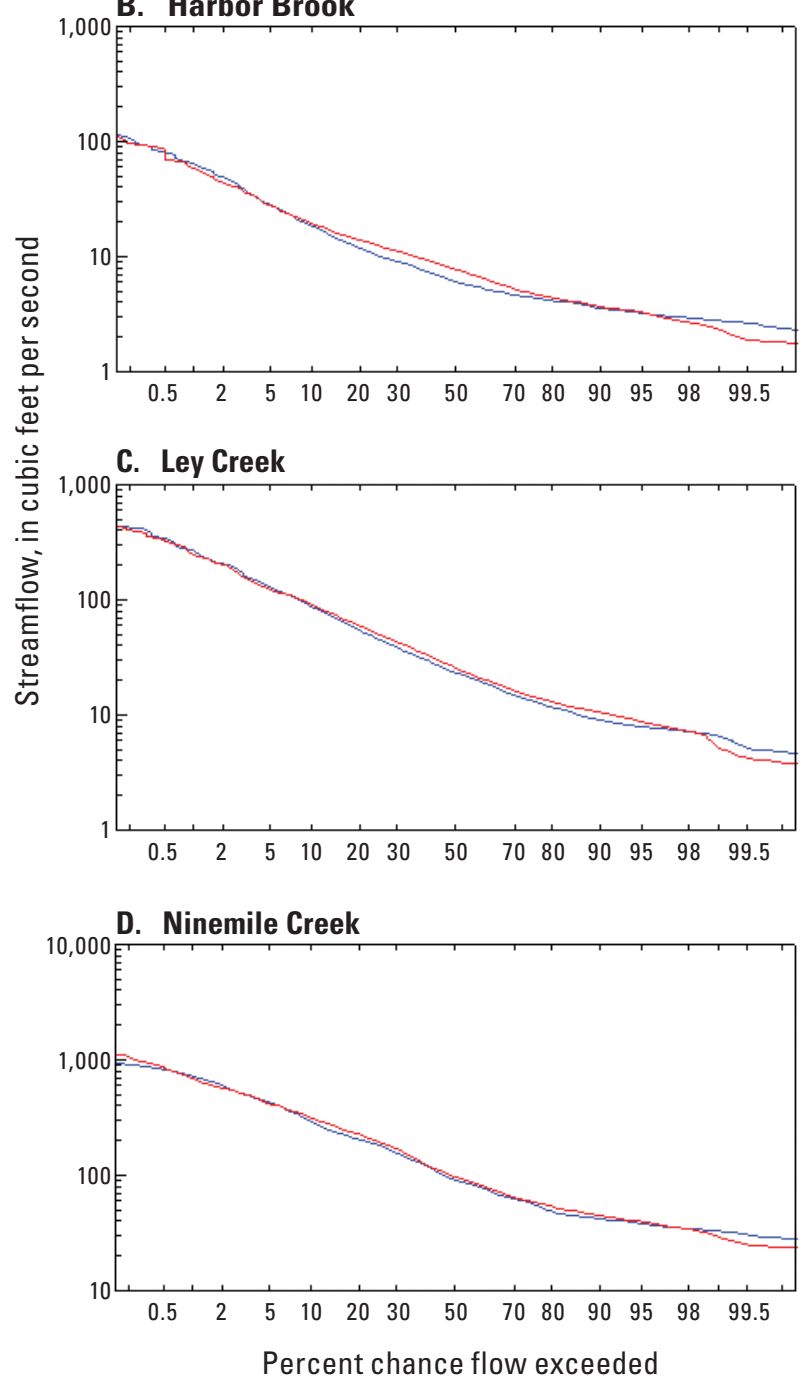

2008 MODEL
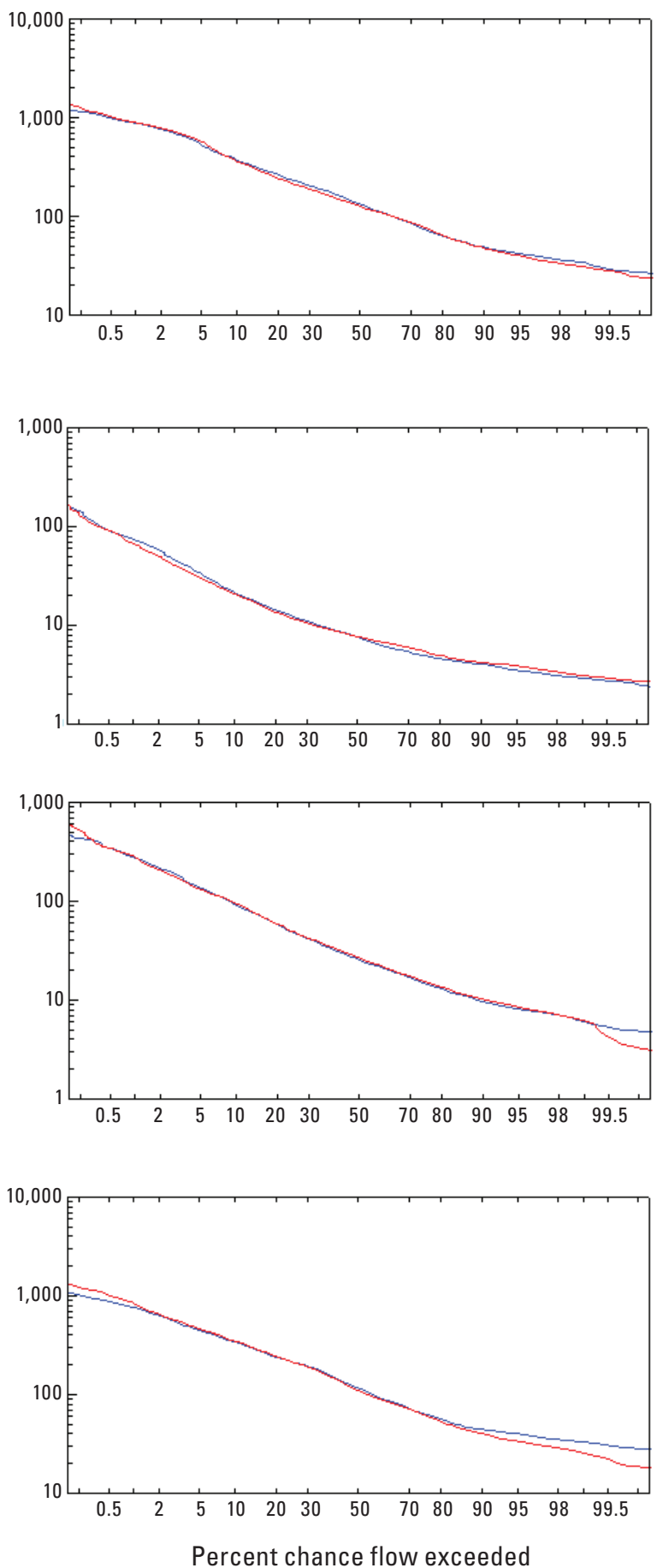

\section{EXPLANATION}

\section{Observed}

Simulated

Figure 5. Flow-duration curves simulated by the 2003 and 2008 versions of the Onondaga Lake Basin model, Onondaga County, New York, at the mouths of major tributaries to the lake: A, Onondaga Creek (reach 137), B, Harbor Brook (reach 206), $C$, Ley Creek (reach 312), and D, Ninemile Creek (reach 443). 
Table 4. Model-performance statistics for 1997-2003 streamflows simulated by the 2008 version of the Onondaga Lake Basin model, Onondaga County, New York, at the mouths of major tributaries to the lake.

[Site locations are shown in figure 1. Bold values indicate statistics that are equal to or better than those computed for streamflows simulated by the 2003 version of the Onondaga Lake Basin model (Coon and Reddy, 2008). $\mathrm{ft}^{3} / \mathrm{s}$, cubic feet per second]

\begin{tabular}{|c|c|c|c|c|c|c|}
\hline Site name and identification number & $\begin{array}{c}\text { Mean } \\
\text { observed } \\
\text { flow } \\
\left(\mathrm{ft}^{3} / \mathrm{s}\right)\end{array}$ & $\begin{array}{c}\text { Mean } \\
\text { simulated } \\
\text { flow } \\
\left(\mathrm{ft}^{3} / \mathbf{s}\right)\end{array}$ & $\begin{array}{l}\text { Correlation } \\
\text { coefficient }\end{array}$ & $\begin{array}{c}\text { Mean error } \\
\text { (bias) } \\
\left(\mathrm{ft}^{3} / \mathrm{s}\right)\end{array}$ & $\begin{array}{c}\text { Mean } \\
\text { error } \\
\text { (percent) }\end{array}$ & $\begin{array}{c}\text { Coefficient } \\
\text { of model-fit } \\
\text { efficiency }\end{array}$ \\
\hline Onondaga Creek at Spencer Street (04240010) & 161 & 160 & 0.90 & -1.06 & -0.66 & $\mathbf{0 . 8 0}$ \\
\hline Harbor Brook at Hiawatha Boulevard (04240105) & 9.72 & 10.0 & .79 & .32 & 3.14 & .61 \\
\hline Ninemile Creek at Lakeland (04240300) & 141 & 151 & .91 & 10.1 & 6.70 & .74 \\
\hline \multicolumn{7}{|c|}{ Monthly mean streamflow } \\
\hline Onondaga Creek at Spencer Street (04240010) & 161 & 160 & 0.95 & -1.01 & -0.63 & 0.90 \\
\hline Harbor Brook at Hiawatha Boulevard (04240105) & 9.74 & 10.1 & .86 & .33 & 3.30 & .74 \\
\hline Ley Creek at Park Street (04240120) & 39.9 & 39.7 & .87 & -.13 & -.32 & .74 \\
\hline
\end{tabular}

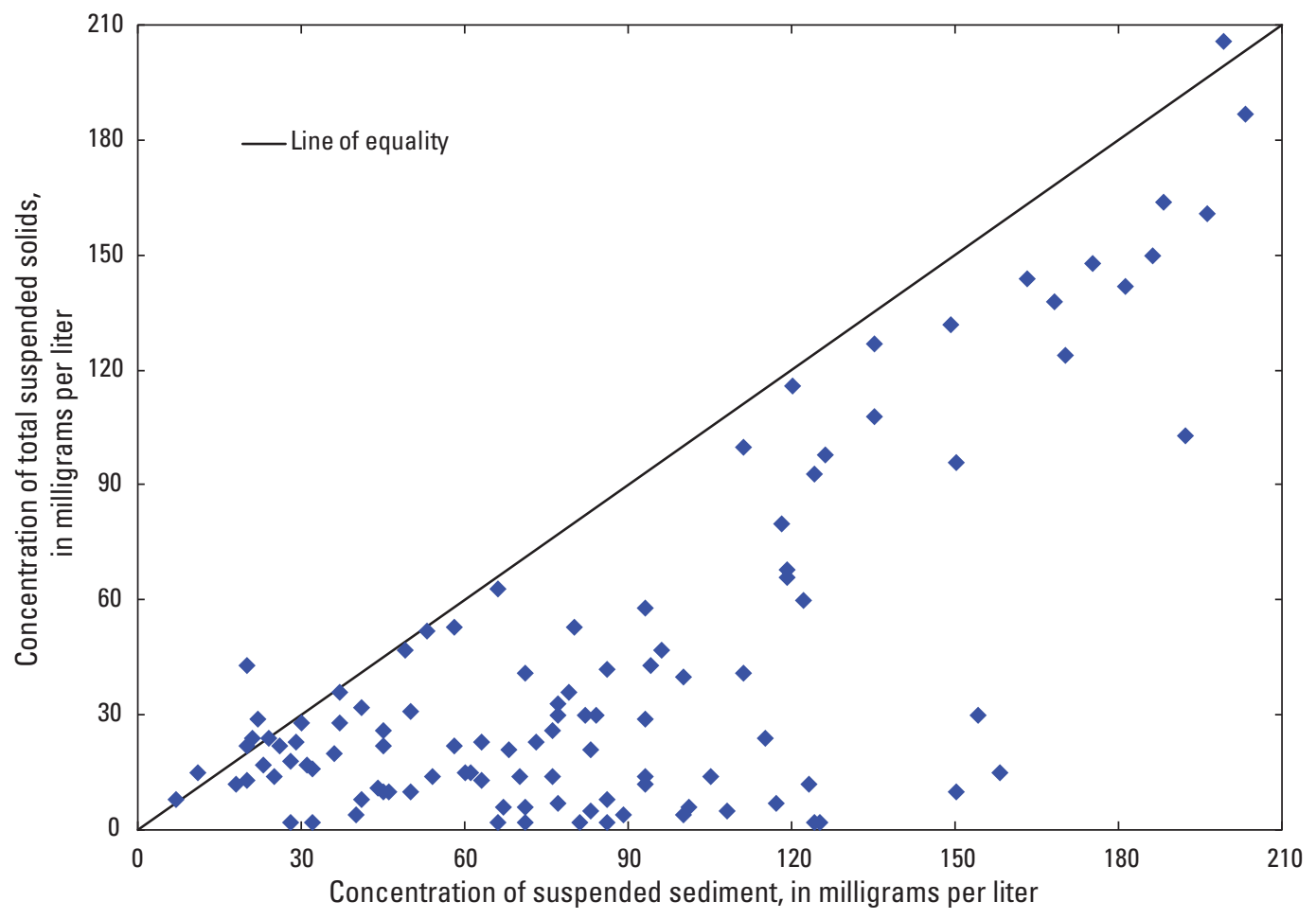

Figure 6. Paired concentrations of total suspended solids and suspended sediment in water samples collected in Onondaga Lake Basin, Onondaga County, New York, 2005-08. 

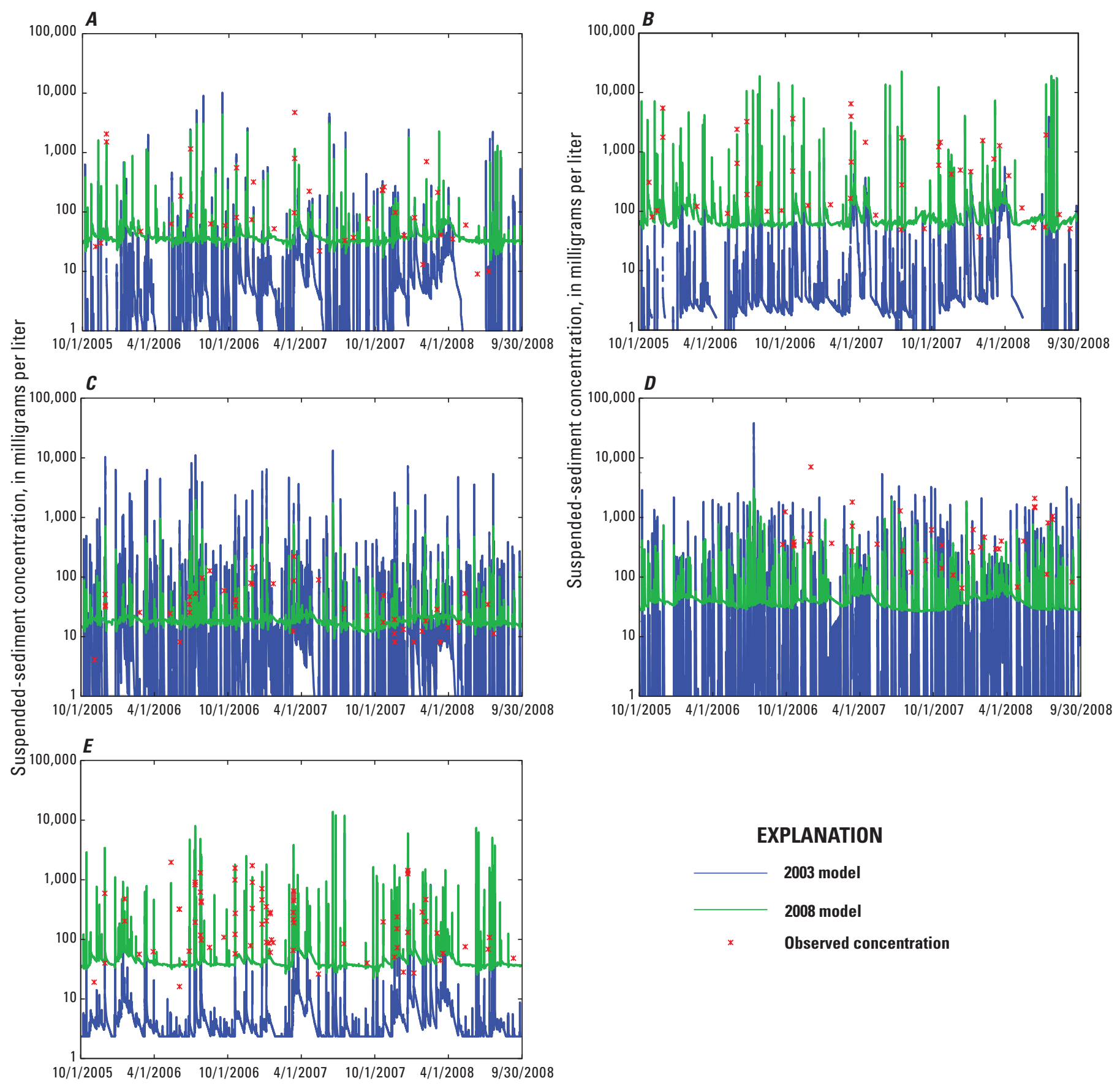

Figure 7. Suspended-sediment concentrations simulated by the 2003 and 2008 versions of the Onondaga Lake Basin model, Onondaga County, New York, for selected headwater subbasins, 2005-08: A, Onondaga Creek (reach 102), B, Rattlesnake Gulf (reach 109), C, North Branch Ley Creek (reach 302), D, South Branch Ley Creek (reach 304), and E, Willow Brook (reach 405). 
section "Creation of New Landslide PERLND") was required to simulate the large storm-related sediment loads that were derived from erosion of landslide materials in and adjacent to the channel.

In a second subbasin, South Branch Ley Creek (fig. 7D), observed base-flow SS concentrations were also high compared to other sites. This subbasin is highly developed, and sediment could be derived from any exposed soil; however, no plausible source of sediment was identified that could justify modifications to the model, as was done for Rattlesnake Gulf. An additional modeling difficulty arose because the magnitude of base-flow SS concentrations varied during the simulation period from more than 100 milligrams per liter $(\mathrm{mg} / \mathrm{L})$ during late 2006 through early 2007 to as low as $50 \mathrm{mg} / \mathrm{L}$ during the last year of the NPS study (2007-08). Coincidentally, some stormflow concentrations were in this same low range; these results indicated that the source of sediment from storm to storm was variable and that either sediment was not always available to be washed off or the precipitation intensity was not great enough to remove large loads of sediment. These inconsistent patterns in SS concentrations made calibration of this site difficult, especially because consistent results were obtained for other calibration sites with similar land uses.

The large discrepancies between the 2003 and 2008 simulations of SS that were noted in flows for the selected headwater subbasins (fig. 7) also were evident at all four calibration sites near the mouths of the major tributaries (fig. 8). Observed SS concentrations were limited to the sites near the mouths of Onondaga Creek (fig. 8A) and Ninemile Creek (fig. 8D). In general, simulations of base-flow SS concentrations by the 2008 model increased, and in most cases, peak concentrations decreased, compared to the results simulated by the 2003 model.

\section{Changes to the Water-Quality Components of the Model}

Concentrations of OP and organic phosphorus (OrgP) were calibrated to the 2005-08 NPS study data. Revisions to parameter values associated with OrgP, which is the major component of $\mathrm{P}$ in surface water, were made to minimize the differences between observed and simulated P concentrations. The accuracies of simulations of nutrient concentrations are subject to the accuracies of simulations of streamflow and sediment concentrations, especially for storm periods. Errors in precipitation records, which affect the magnitude and timing of peak flows, will consequently introduce errors in simulated nutrient concentrations.

\section{Orthophosphate Concentrations}

Revisions to parameter values that were made to calibrate OP concentrations in the 2008 model were applied consistently to each land type in all of the five major subdivisions of the Onondaga Lake Basin (fig. 2), except for the following parameters and land types. The rate at which $\mathrm{OP}$ accumulated
(ACQOP) and the maximum storage of OP on the land surface (SQOLIM) varied by subdivision for row-crop, farmstead, and developed land. The concentration of OP in interflow outflow (IOQC) for row-crop and farmstead land in the Otisco Lake subbasin (area D in fig. 2) differed from IOQC values applied to the same land uses elsewhere in the Onondaga Lake Basin. Similarly, the concentration of OP in groundwater outflow (AOQC) for developed land types in the Harbor Brook subbasin (area C in fig. 2), wetlands in the Otisco Lake subbasin and most land types in the middle Ninemile Creek subbasin (area $\mathrm{E}$ in fig. 2) differed from $\mathrm{AOQC}$ values applied to the same land types elsewhere in the Onondaga Lake Basin.

OP concentrations simulated in base and peak flows by the 2003 model generally were too low and too high, respectively, when compared with observed data from selected headwater subbasins (figs. 9A, B, and E). Simulated concentrations at the mouths of the major tributaries by both versions of the model were relatively close (fig. 10), except for Harbor Brook (fig. 10B). On this stream, at Hiawatha Boulevard (site 04240105; fig. 1), the observed data displayed an unexplainable upward trend in OP concentrations, and 2008-model revisions attempted to mimic this pattern by using the HSPF special-actions module to periodically change the concentration of OP in groundwater outflows from PERLNDs in the Harbor Brook subbasin. At the mouth of Ninemile Creek (fig. 10D), both model versions generated OP concentrations that were high compared to observed values. This discrepancy was unresolvable given that properly calibrated OP concentrations from upstream sites resulted in at-the-mouth concentrations that could not be lowered to the range indicated by the observed values. No plausible explanation for a decrease in observed OP concentrations at the mouth of Ninemile Creek around the beginning of 2007 could be offered.

\section{Phosphorus Concentrations}

Phosphorus concentrations were affected by the combined calibrations of $\mathrm{OP}$ and $\mathrm{OrgP}$ concentrations to observed values. Because OP typically is a much smaller component of $\mathrm{P}$ than $\mathrm{OrgP}$, revisions to parameter values that control OrgP concentrations were made to improve the fit between observed and simulated $\mathrm{P}$ concentrations. These revisions were applied consistently to each land type in all of the five major subdivisions of the Onondaga Lake Basin (fig. 2). Phosphorus concentrations simulated by both versions of the model were relatively close to observed concentrations. Noticeable differences between model simulations were evident for North Branch Ley Creek (fig. 11C) and South Branch Ley Creek (fig. 11D), where base-flow concentrations from the 2008 model were lower than those from the 2003 model, and for Willow Brook (fig. 11E), where 2008-model concentrations were greater than those from the 2003 model. These changes reflected revisions to model parameter values for subbasins dominated respectively by wetlands (North Branch Ley Creek), developed areas (South Branch Ley 

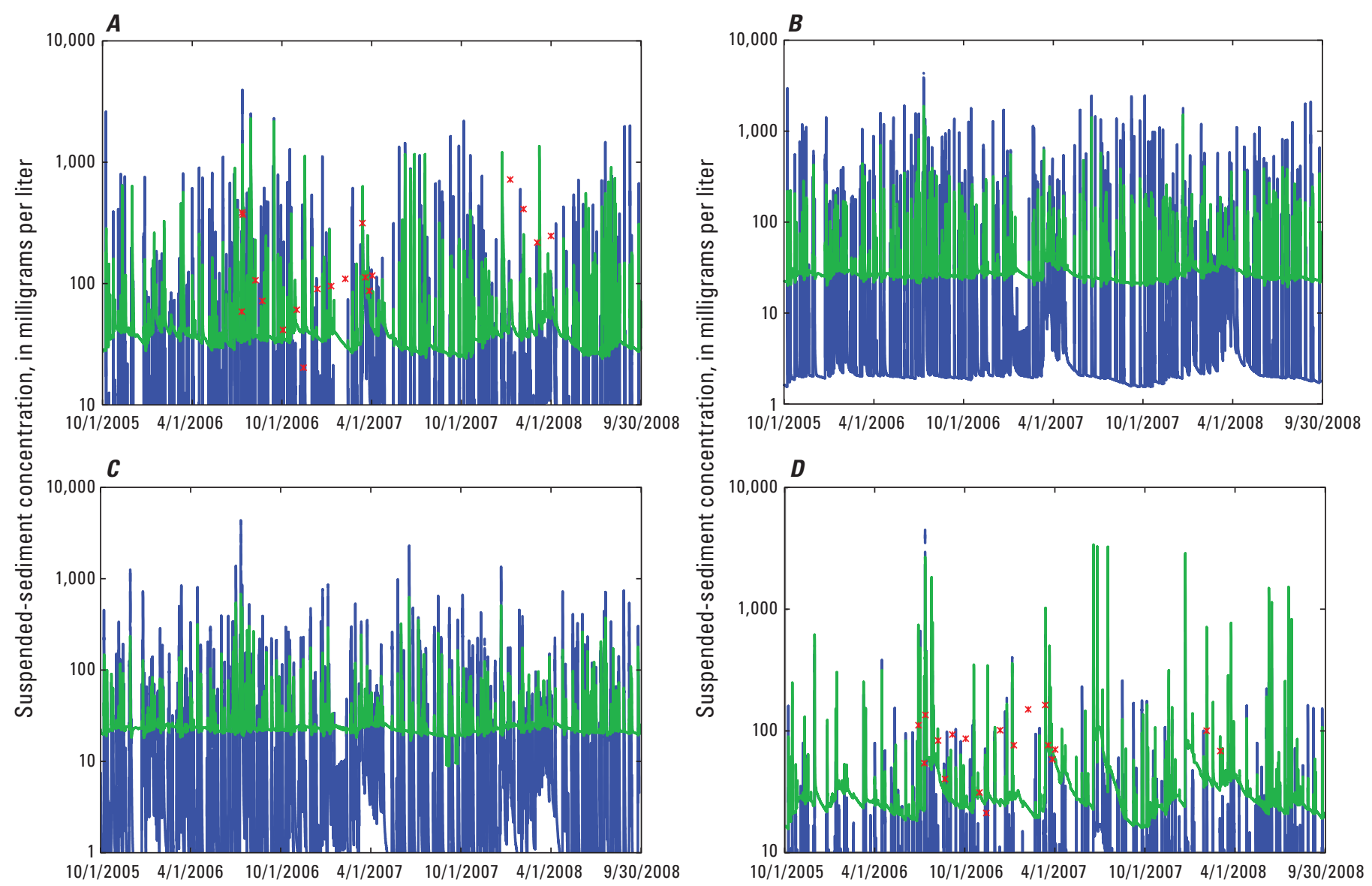

EXPLANATION

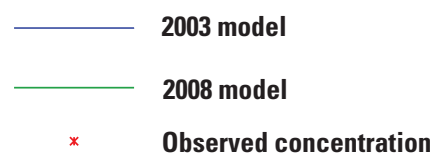

Figure 8. Suspended-sediment concentrations simulated by the 2003 and 2008 versions of the Onondaga Lake Basin model, Onondaga County, New York, at the mouths of major tributaries to the lake, 2005-08: A, Onondaga Creek (reach 137), B, Harbor Brook (reach 206), $C$, Ley Creek (reach 312), and D, Ninemile Creek (reach 443). 

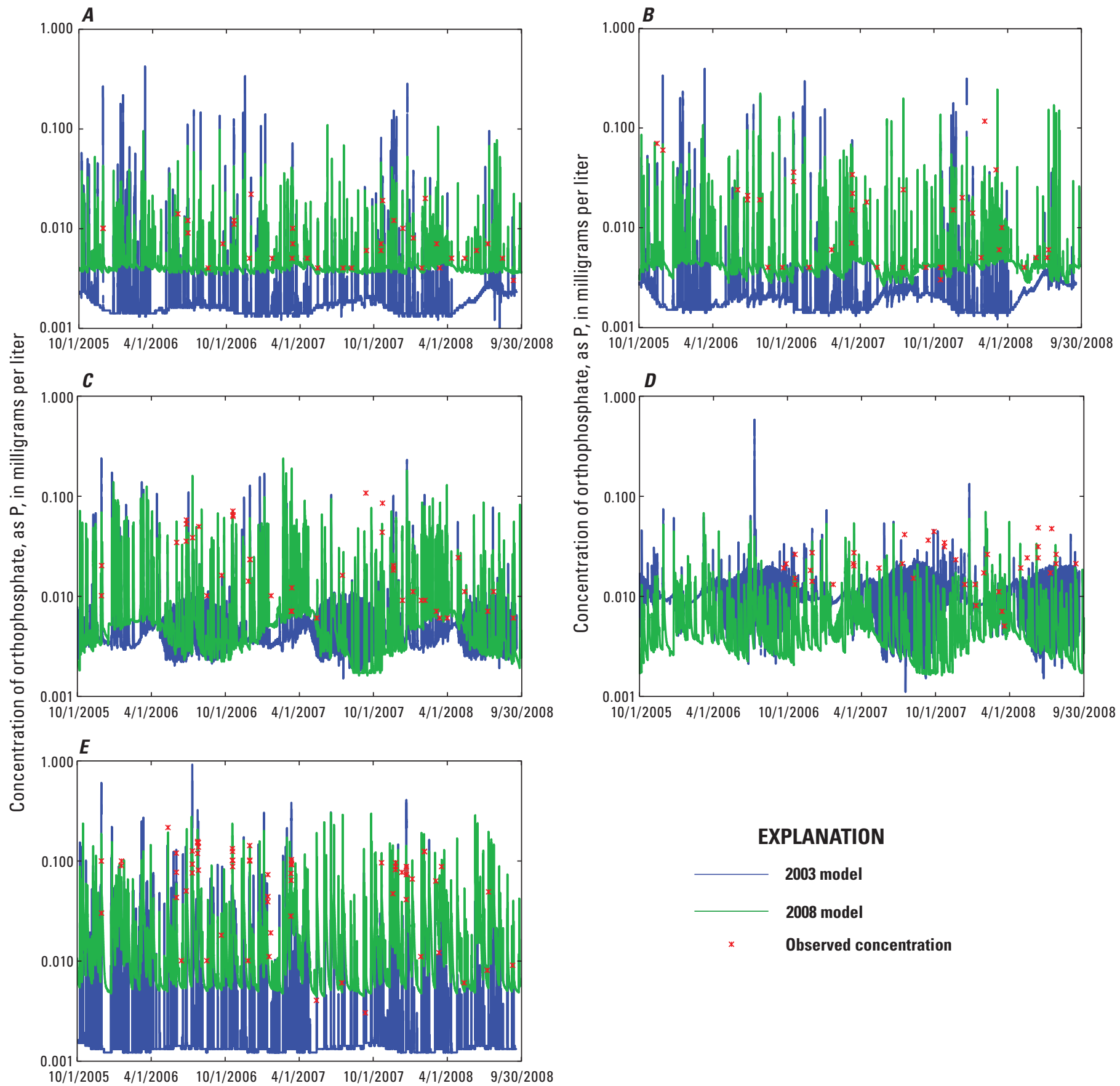

Figure 9. Concentrations of orthophosphate, as phosphorus (P), simulated by the 2003 and 2008 versions of the Onondaga Lake Basin model, Onondaga County, New York, for selected headwater subbasins, 2005-08: $A$, Onondaga Creek (reach 102), B, Rattlesnake Gulf (reach 109), C, North Branch Ley Creek (reach 302), D, South Branch Ley Creek (reach 304), and E, Willow Brook (reach 405). 

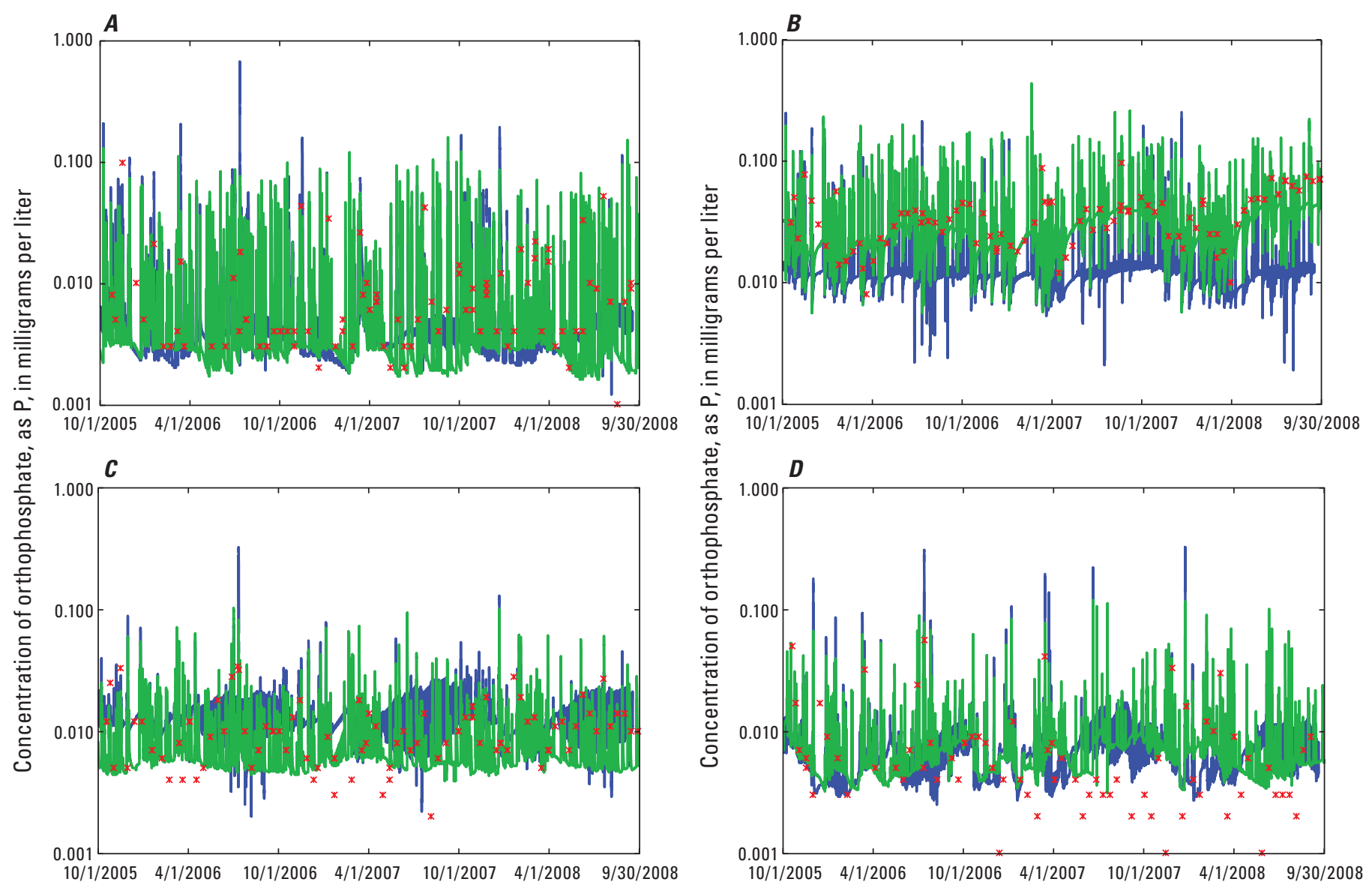

\section{EXPLANATION}

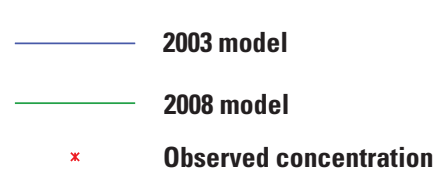

Figure 10. Concentrations of orthophosphate, as phosphorus (P), simulated by the 2003 and 2008 versions of the Onondaga Lake Basin model, Onondaga County, New York, at the mouths of major tributaries to the lake, 2005-08: A, Onondaga Creek (reach 137), B, Harbor Brook (reach 206), C, Ley Creek (reach 312), and D, Ninemile Creek (reach 443). 

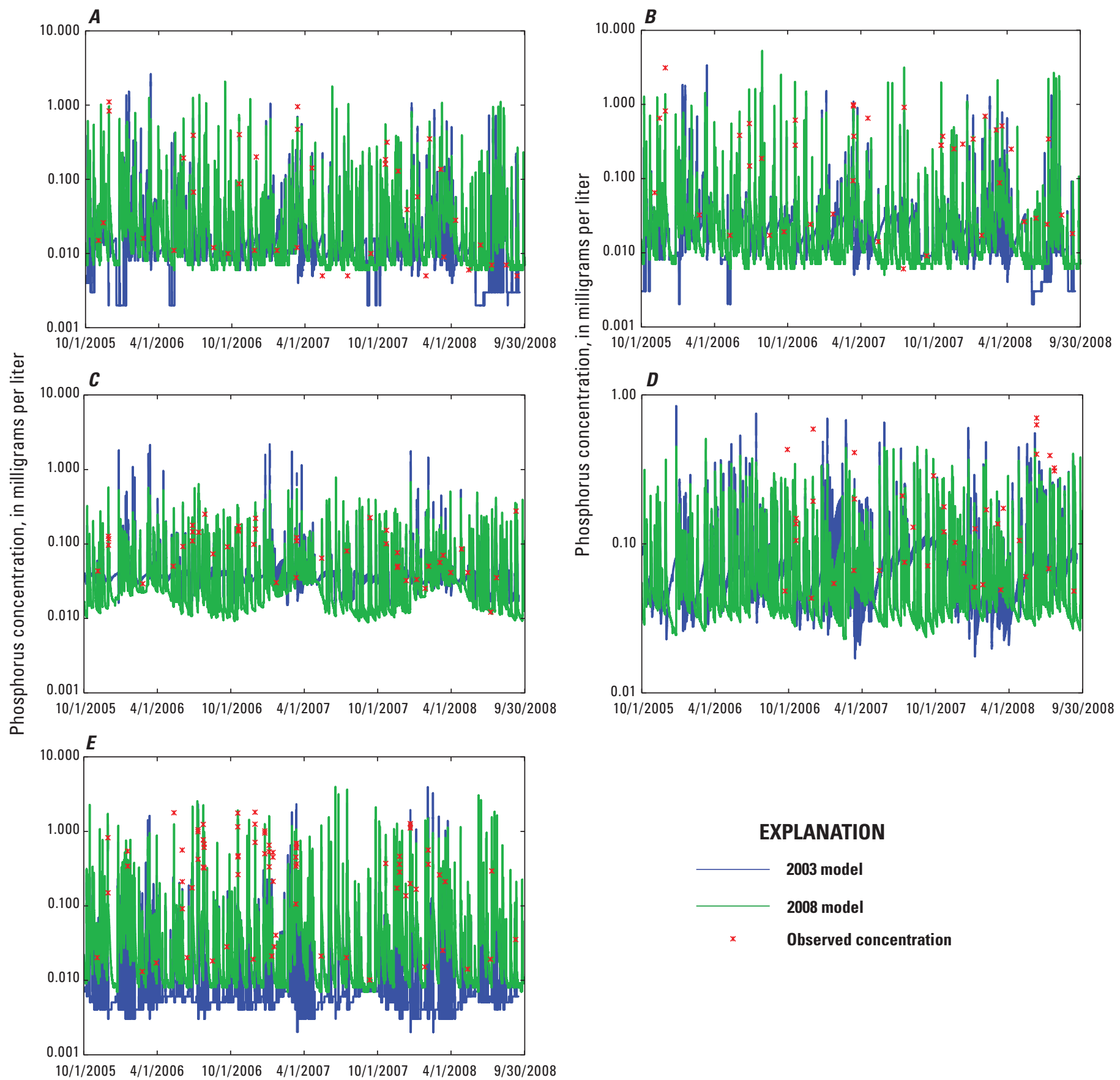

Figure 11. Phosphorus concentrations simulated by the 2003 and 2008 versions of the Onondaga Lake Basin model, Onondaga County, New York, for selected headwater subbasins, 2005-08: A, Onondaga Creek (reach 102), B, Rattlesnake Gulf (reach 109), $C$, North Branch Ley Creek (reach 302), $D$, South Branch Ley Creek (reach 304), and E, Willow Brook (reach 405). 
Creek), and agricultural uses (Willow Brook). The effects of the 2008-model revisions associated with developed areas were also evident in the $\mathrm{P}$ concentrations simulated for the sites at the mouths of the major tributaries, where lower $\mathrm{P}$ concentrations were simulated compared to the 2003 model (fig. 12). The exception was Harbor Brook (fig. 12B) where, as for OP concentrations at Hiawatha Boulevard (site 04240105; fig. 1), an unexplainable, albeit less pronounced, upward trend in observed $\mathrm{P}$ concentrations necessitated the simulation of higher concentrations by the 2008 model than had been required for calibration of the 2003 model.

\section{Chloride Concentrations in Onondaga Creek}

Chloride $(\mathrm{Cl})$ concentrations, which were not simulated by the 2003 model, were simulated by the 2008 model to address questions regarding the magnitude of salt contributions to Onondaga Lake from Onondaga Creek during 2010. The existence of brine springs along Onondaga Creek has been known since the mid-1700s, and commercial production of salt was a main industry in the Syracuse area during the 18th and 19th centuries (Kappel, 2000). The average of measured $\mathrm{Cl}$ concentrations ranged from less than $30 \mathrm{mg} / \mathrm{L}$ in the headwaters area of the basin (McKenna and others, 1999) to $300-400 \mathrm{mg} / \mathrm{L}$ near Cardiff (site 04237962; fig. 1) and 600-700 mg/L near the mouth of Onondaga Creek (from data provided by Antonio Deskins, Onondaga County Department of Water Environment Protection, written commun., 2008).

The 2008 model was modified to include simulation of chloride concentrations in the Onondaga Creek Basin only. The model was calibrated to $\mathrm{Cl}$ concentrations measured by OCWEP at monitoring sites near Cardiff (site 04237962), at Dorwin Avenue (site 04239000), at Spencer Street (site 04240010), and at Kirkpatrick Street (site 04240011, fig. 1; table 1). The simulated concentrations matched the range and seasonal pattern of observed concentrations (fig. 13). Concentrations were inversely related to flow; that is, $\mathrm{Cl}$ concentrations decreased with increasing flow. Concentrations increased substantially between Dorwin Avenue at the southern boundary of Syracuse and Spencer Street about 5 miles (mi) downstream and within $1 \mathrm{mi}$ of the creek's mouth. The source of this salt has not been determined, but the increase in $\mathrm{Cl}$ concentrations along this reach of Onondaga Creek has been documented previously (Effler and Whitehead, 1996) and might be attributed to groundwater brine discharges. $\mathrm{Cl}$ concentrations almost double in magnitude between Spencer Street and Kirkpatrick Street, $0.15 \mathrm{mi}$ downstream, where springs discharge brine directly into the creek. The largest of these springs has a Cl concentration of about $60,000 \mathrm{mg} / \mathrm{L}$ and is a large contributor of salt to Onondaga Lake (Yager and others, 2007). As a result of the high background concentrations from these continuous groundwater discharges, the expected wintertime increase in concentrations that often results from the application of road-deicing salt in urban areas (Hayhurst and others, 2010) was obscured. Adjustments were made to the simulated concentrations by inputting time series of $\mathrm{Cl}$ loads that varied by time and input location on the basis of intermittent discharges of brackish and saline groundwater to Onondaga Creek from 2006 to 2009 during Onondaga County sewer-construction projects (Janaki Suryadevara, Onondaga County Department of Water Environment Protection, written commun., 2010).

\section{Model Applications}

Following recalibration, the 2008 model was used to compute sediment and phosphorus loading rates from the various land types in the basin, compute the loads of sediment and phosphorus that were generated within each subbasin, and estimate the probable contributions of phosphorus from each subbasin to Onondaga Lake. Chloride concentrations in Onondaga Creek were simulated to assess the relative contributions of salt from different sources in the basin and to estimate the loads of $\mathrm{Cl}$ that were entering Onondaga Lake from this tributary. Scenarios of land-use changes and best-management practices can be developed, and model output can be used, to evaluate the effects that these changes or practices are likely to have on sediment and phosphorus loads entering Onondaga Lake. As an example, the model was revised to reflect basin conditions prior to European colonization (forested instead of agricultural or developed land) to estimate the probable minimum phosphorus loading to Onondaga Lake.

\section{Sediment and Phosphorus Loading Rates}

Average annual loading rates for sediment and phosphorus (both OP and OrgP) were computed by the 2008 model of the Onondaga Lake Basin for the water years 1998-2008. The basin was divided into five major hydrologic areas for modeling purposes (fig. 2), and loading rates for each of the pervious and impervious land types within each area were compiled (table 5). Differences among the rates from the different areas were not unexpected. Variable precipitation inputs used in the model, the failure of a single precipitation record to adequately represent nonuniform precipitation patterns across the basin, and localized differences in topography and land-management practices not accounted for in the creation of the PERLNDs and IMPLNDs necessitated the use of different parameter values to simulate and calibrate surface runoff, sediment washoff, and nutrient processes. These factors and the different resultant sets of parameter values produced different loading rates, a common and predictable outcome of watershed modeling.

The average of the five area loading rates for each land type (table 5) can be used as estimates of basinwide loading rates. (Total phosphorus loading rates can be estimated from the sum of the $\mathrm{OP}$ and $\mathrm{OrgP}$ values.) Loading rates were largest for farmstead and row-crop land uses for all three 

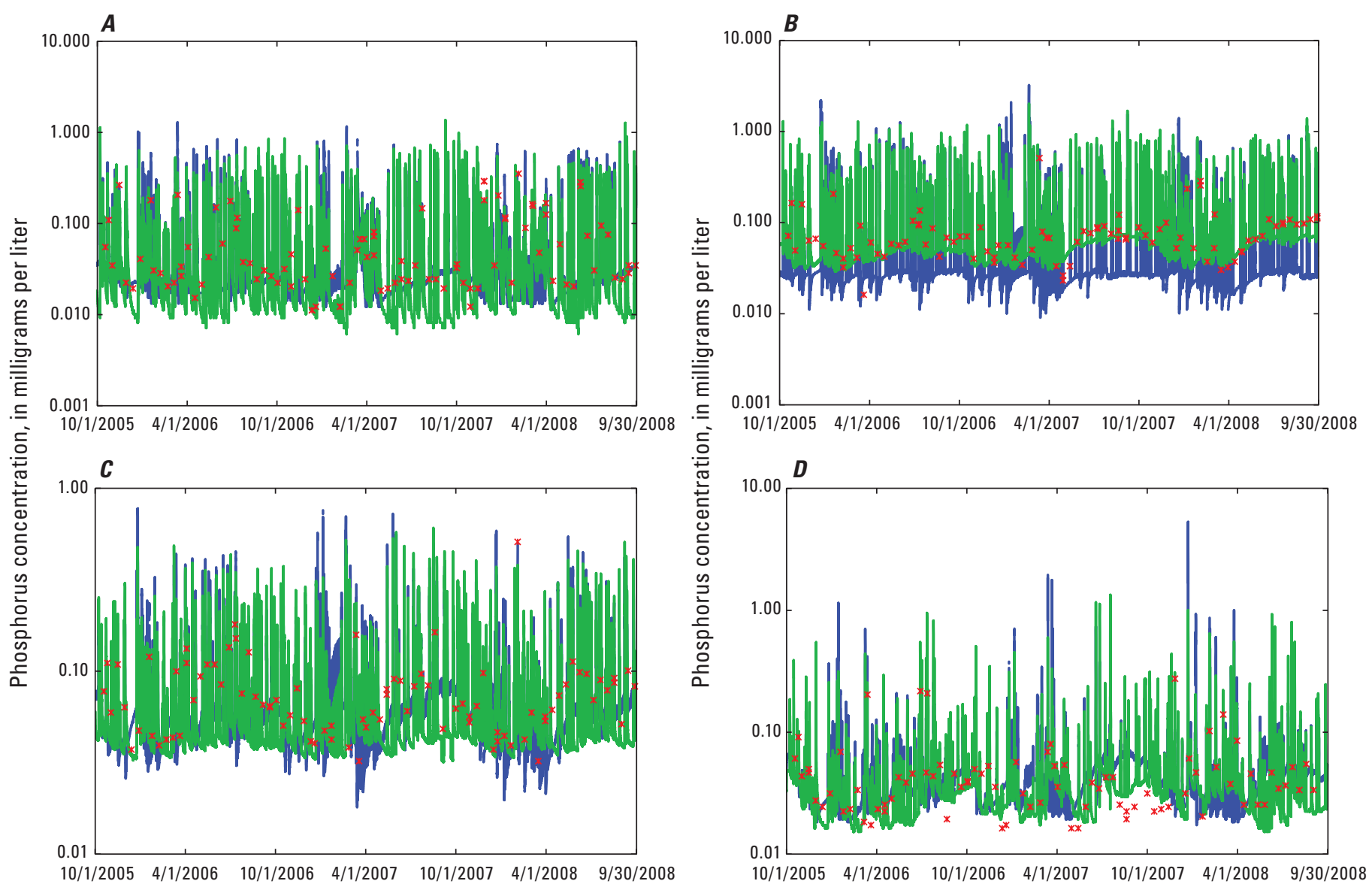

EXPLANATION

2003 model

2008 model

Observed concentration

Figure 12. Phosphorus concentrations simulated by the 2003 and 2008 versions of the Onondaga Lake Basin model, Onondaga County, New York, at the mouths of major tributaries to the lake, 2005-08: A, Onondaga Creek (reach 137), B, Harbor Brook (reach 206), C, Ley Creek (reach 312), and D, Ninemile Creek (reach 443). 

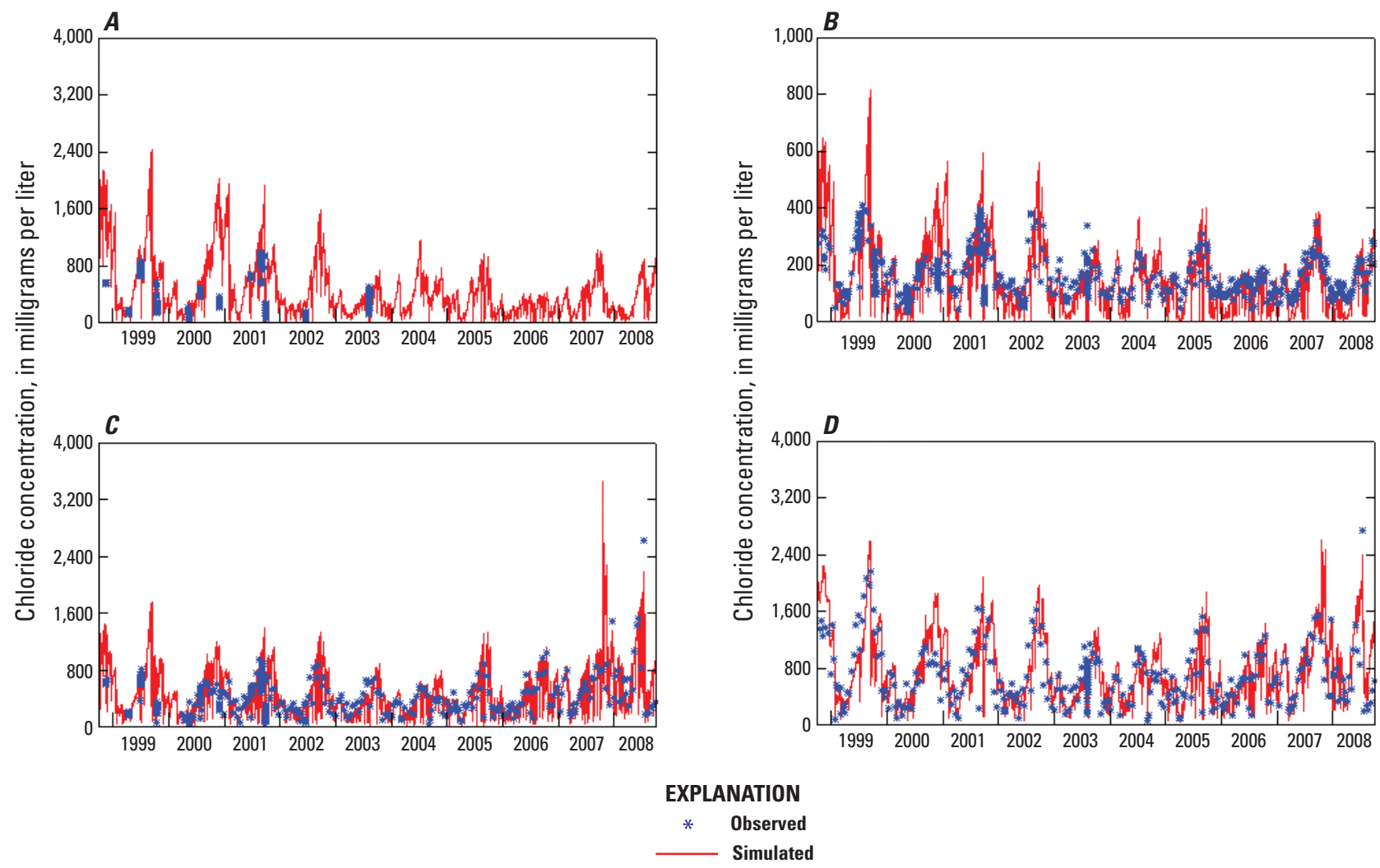

Figure 13. Observed and simulated chloride concentrations along Onondaga Creek, Onondaga County, New York: $A$, near Cardiff (site 04237962), B, at Dorwin Avenue (site 04239000), C, at Spencer Street (site 04240010), and D, at Kirkpatrick Street (site 04240011).

constituents-SS, OP, and OrgP. The lowest sediment loading rates were for wetlands, followed by forested land with high infiltration rates and low runoff potentials. Forests had the lowest loading rates of both OP and OrgP. The average annual precipitation during the simulation period, 39.2 inches (in.), approximated the 30 -year normal precipitation, $40.0 \mathrm{in}$., as recorded by the NWS at the Syracuse Hancock International Airport (National Weather Service, 2011). This similarity suggests that the climatic conditions that existed during the model simulation period were representative of long-term conditions, and thus that the computed loading rates can be considered representative of long-term rates in Onondaga County.

The average annual loading rates for water years 19982008 for the five major subdivisions in the Onondaga Lake Basin that were estimated by the two versions of the model are compared in table 6 . Sediment loading rates for all land types, except wetlands, were higher in the results from the 2008 model than from the 2003 model. (As explained previously, this increase resulted from calibration of the model to SS, rather than TSS, concentrations.) Relative to the 2003 model, the 2008-model loading rates of OP increased, and those of OrgP decreased, for row-crop, farmstead, and wetland land types; loading rates of OrgP increased for forested, pasturehay, and developed land types.

\section{Subbasin Loads of Sediment and Phosphorus}

Average annual yields of SS (fig. 14), OP, and P (figs. 15A and B) from each modeled subbasin were computed by subtracting the subbasin input load (that is, the load from upstream subbasins that entered a given subbasin reach) from the output load (the total load that exited a given subbasin reach) and dividing by the subbasin area. These values reflected the constituent contributions from the land segments and the gains or losses from instream processes within each subbasin. 
Table 5. Average annual sediment and phosphorus loading rates for water years 1998-2008 from pervious and impervious land types in five major subdivisions of the Onondaga Lake Basin simulated by the 2008 version of the precipitation-runoff model of the Onondaga Lake Basin, Onondaga County, New York.

[Specified areas are identified in figure 2. A, Upper and middle Onondaga Creek Basins; B, Ley Creek and lower Onondaga and Ninemile Creek Basins; C, Harbor Brook Basin; D, Otisco Lake Basin; and E, Middle Ninemile Creek and West Branch Onondaga Creek Basins. CSO, combined sewer overflow; ,-- no data]

\begin{tabular}{|c|c|c|c|c|c|c|}
\hline \multirow{2}{*}{ Land type } & \multicolumn{6}{|c|}{ Sediment loading rates (short tons per acre per year) } \\
\hline & Area A & Area B & Area C & Area D & Area $\mathrm{E}$ & Average \\
\hline Forest with low runoff potential & 0.05 & 0.002 & 0.001 & 0.07 & 0.06 & 0.04 \\
\hline Pasture-hay with low runoff potential & .12 & .008 & .002 & .21 & .18 & .10 \\
\hline Pasture-hay with high runoff potential & .77 & .46 & .42 & 1.02 & .80 & .69 \\
\hline Row crops & 2.06 & .36 & .36 & 3.10 & 2.77 & 1.73 \\
\hline Wetland & 0.00 & 0.00 & 0.00 & 0.00 & 0.00 & 0.00 \\
\hline Landslide & 30.3 & -- & -- & -- & -- & 30.3 \\
\hline Low-intensity residential & .26 & .17 & .16 & .32 & .30 & .24 \\
\hline High-intensity residential & .42 & .23 & .21 & .56 & .32 & .35 \\
\hline Commercial/industrial/transportation & .51 & .27 & .24 & .74 & .64 & .48 \\
\hline \multirow{2}{*}{ CSO commercial/industrial/transportation } & \multicolumn{6}{|c|}{ Orthophosphate, as phosphorus, loading rates (pounds per acre per year) } \\
\hline & Area A & Area B & Area C & Area D & Area E & Average \\
\hline Forest with low runoff potential & .017 & .016 & .010 & .021 & .017 & .02 \\
\hline Forest with high runoff potential & .018 & .018 & .012 & .021 & .018 & .02 \\
\hline Pasture-hay with low runoff potential & .020 & .018 & .010 & .024 & .020 & .02 \\
\hline Pasture-hay with high runoff potential & .021 & .020 & .015 & .025 & .022 & .02 \\
\hline Row crops & .145 & .076 & .061 & .775 & .260 & .26 \\
\hline Farmstead & .254 & -- & .172 & 1.61 & .910 & .74 \\
\hline Wetland & .139 & .142 & .088 & .254 & .234 & .17 \\
\hline Low-intensity residential & .085 & .065 & .052 & .097 & .089 & .08 \\
\hline CSO commercial/industrial/transportation & Area A & Area B & Area C & Area D & Area E & Average \\
\hline Forest with low runoff potential & .06 & .009 & .006 & .09 & .08 & .05 \\
\hline Forest with high runoff potential & .14 & .08 & .08 & .18 & .16 & .13 \\
\hline Pasture-hay with low runoff potential & .10 & .014 & .009 & .14 & .13 & .08 \\
\hline Pasture-hay with high runoff potential & .30 & .18 & .16 & .38 & .33 & .27 \\
\hline Row crops & 1.18 & .31 & .30 & 1.56 & 1.45 & .96 \\
\hline Farmstead & 8.91 & -- & 3.30 & 11.3 & 10.9 & 8.60 \\
\hline Wetland & .08 & .06 & .02 & .11 & .11 & .08 \\
\hline Low-intensity residential & .49 & .43 & .42 & .53 & .52 & .48 \\
\hline High-intensity residential & .77 & .70 & .63 & .86 & .33 & .66 \\
\hline Commercial/industrial/transportation & .96 & .85 & .78 & 1.11 & 1.07 & .95 \\
\hline CSO low-intensity residential & -- & .45 & .42 & -- & -- & .44 \\
\hline CSO high-intensity residential & -- & .54 & .71 & -- & -- & .63 \\
\hline CSO commercial/industrial/transportation & -- & .67 & .86 & -- & -- & .77 \\
\hline
\end{tabular}


Table 6. Average annual sediment and phosphorus loading rates for water years 1998-2008 from pervious land types in five major subdivisions of the Onondaga Lake Basin simulated by the 2003 and 2008 versions of the precipitation-runoff model of the Onondaga Lake Basin, Onondaga County, New York.

[Values are averages of loading rates from the five simulated areas shown in figure 2. Values in bold type are the higher of the two associated values]

\begin{tabular}{|c|c|c|c|c|c|c|}
\hline \multirow[t]{2}{*}{ Land type } & \multicolumn{2}{|c|}{$\begin{array}{c}\text { Sediment } \\
\text { (short tons per acre per year) }\end{array}$} & \multicolumn{2}{|c|}{$\begin{array}{c}\text { Orthophosphate, as } \mathrm{P} \\
\text { (pounds per acre per year) }\end{array}$} & \multicolumn{2}{|c|}{$\begin{array}{c}\text { Organic phosphorus } \\
\text { (pounds per acre per year) }\end{array}$} \\
\hline & 2003 model & 2008 model & 2003 model & 2008 model & 2003 model & 2008 model \\
\hline Forest with low runoff potential & 0.01 & 0.04 & 0.02 & 0.02 & 0.03 & 0.05 \\
\hline Forest with high runoff potential & .10 & .17 & .02 & .02 & .07 & .13 \\
\hline Pasture-hay with low runoff potential & .04 & .10 & .02 & .02 & .06 & .08 \\
\hline Pasture-hay with high runoff potential & .32 & .69 & .02 & .02 & .18 & .27 \\
\hline Row crops & .45 & 1.73 & .04 & .26 & 1.12 & .96 \\
\hline Farmstead & 1.28 & 3.11 & .25 & .74 & 9.58 & 8.60 \\
\hline Wetland & 0.00 & 0.00 & .04 & .17 & .10 & .08 \\
\hline Low-intensity residential & .10 & .24 & .08 & .08 & .08 & .48 \\
\hline High-intensity residential & .13 & .35 & .13 & .09 & .11 & .66 \\
\hline Commercial/industrial/transportation & .18 & .48 & .13 & .10 & .29 & .95 \\
\hline
\end{tabular}

Negative yields of SS, OP, and P that are associated with subbasin 121 reflect the mitigative effects of the Onondaga Reservoir at the confluence of Onondaga Creek and West Branch Onondaga Creek on these constituents. The negative yields of these constituents in subbasin 409 are attributed to the mitigative effects of Otisco Lake. The negative yield of SS in subbasin 138 is a result of the backwater effect of Onondaga Lake on the harbor at the mouth of Onondaga Creek. The high SS yields from subbasins 105 and 109 were generated from the erosion of landslide materials in Rainbow Creek and Rattlesnake Gulf Basins, respectively. High OP and P yields in subbasin 423 are a result of the estimated nutrient discharges from the wastewater-treatment plant in Marcellus (fig. 1). Other subbasins with high yields of OP and $\mathrm{P}$ generally had large areas of agricultural or developed land.

\section{Watershed-Management Analysis}

Once OP and P loads and yields had been computed for individual subbasins (fig. 15), the model was used to estimate the portion of each load that was likely to contribute to the total loads entering Onondaga Lake. The objective of this analysis was to enable targeting of proposed remediation projects in areas of the basin that would result in the greatest load decrease for a given financial and manpower investment. The model was repeatedly modified by removing each subbasin, in turn, from the simulation. The total loads at the mouth of each major tributary to Onondaga Lake were output for each run and compared to the loads simulated by the calibrated 2008 model. The difference in loads entering the lake was assumed to be the incremental contribution from the removed subbasin. Output from these model runs are presented in paired figures that show the average annual yields (in pounds per acre) generated within a subbasin for orthophosphate (fig. 16A) and phosphorus (fig. 17A) and the subbasin yields of orthophosphate (fig. 16B) and phosphorus (fig. 17B) that are transported through the watershed to Onondaga Lake.

The general conclusion that can be drawn from these comparative figures is that subbasins with large yields in the headwater areas of the Onondaga Lake Basin are less likely to be major contributors of $\mathrm{P}$ and OP to the lake than subbasins proximal to the lake. This is particularly applicable to the subbasins upstream from the Onondaga Reservoir (subbasin 121) and Otisco Lake (subbasin 409), each of which has a mitigative effect on input loads. Conversely, large loads that are generated in subbasins proximal to Onondaga Lakethat is, the urban subbasins in Syracuse - are less likely to be naturally mitigated, and the contributions of $\mathrm{P}$ and OP to the lake are high. Remediation of loads derived from these subbasins would produce the greatest load-reduction benefits to Onondaga Lake. 

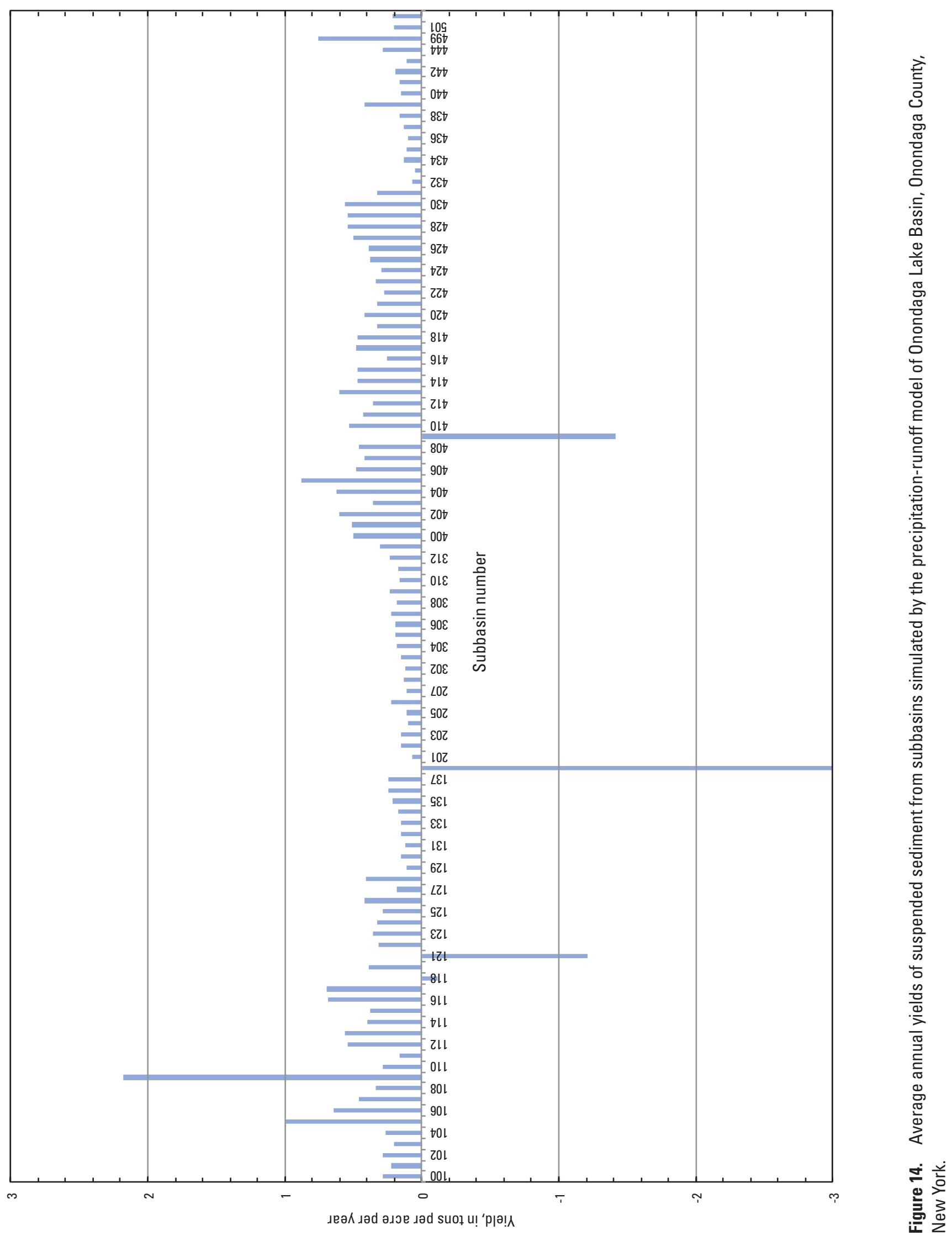


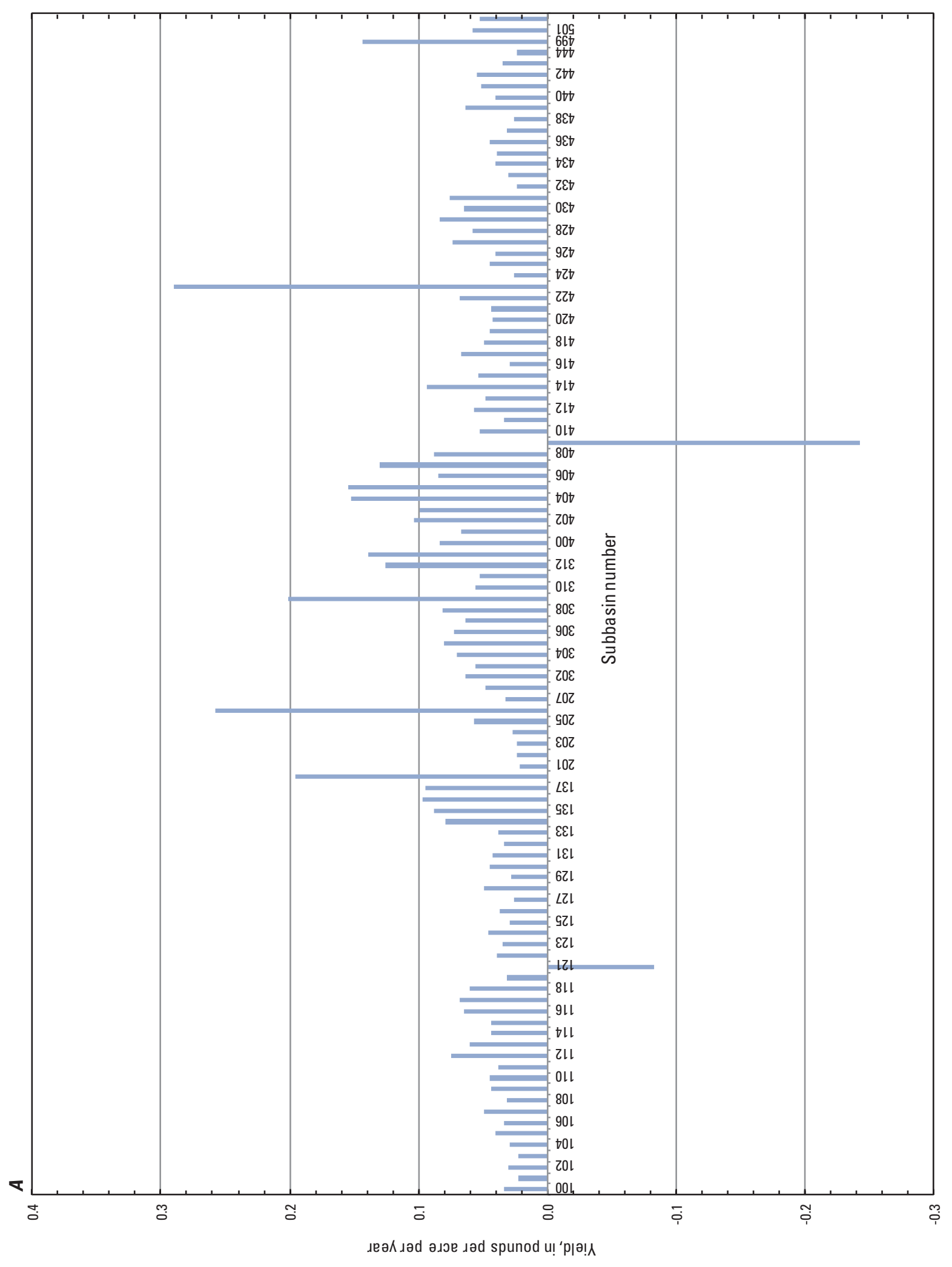

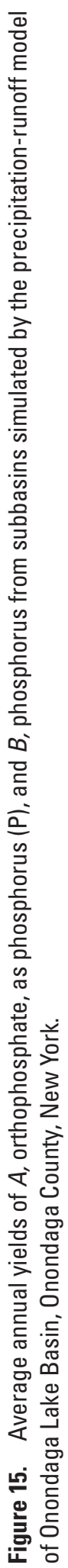




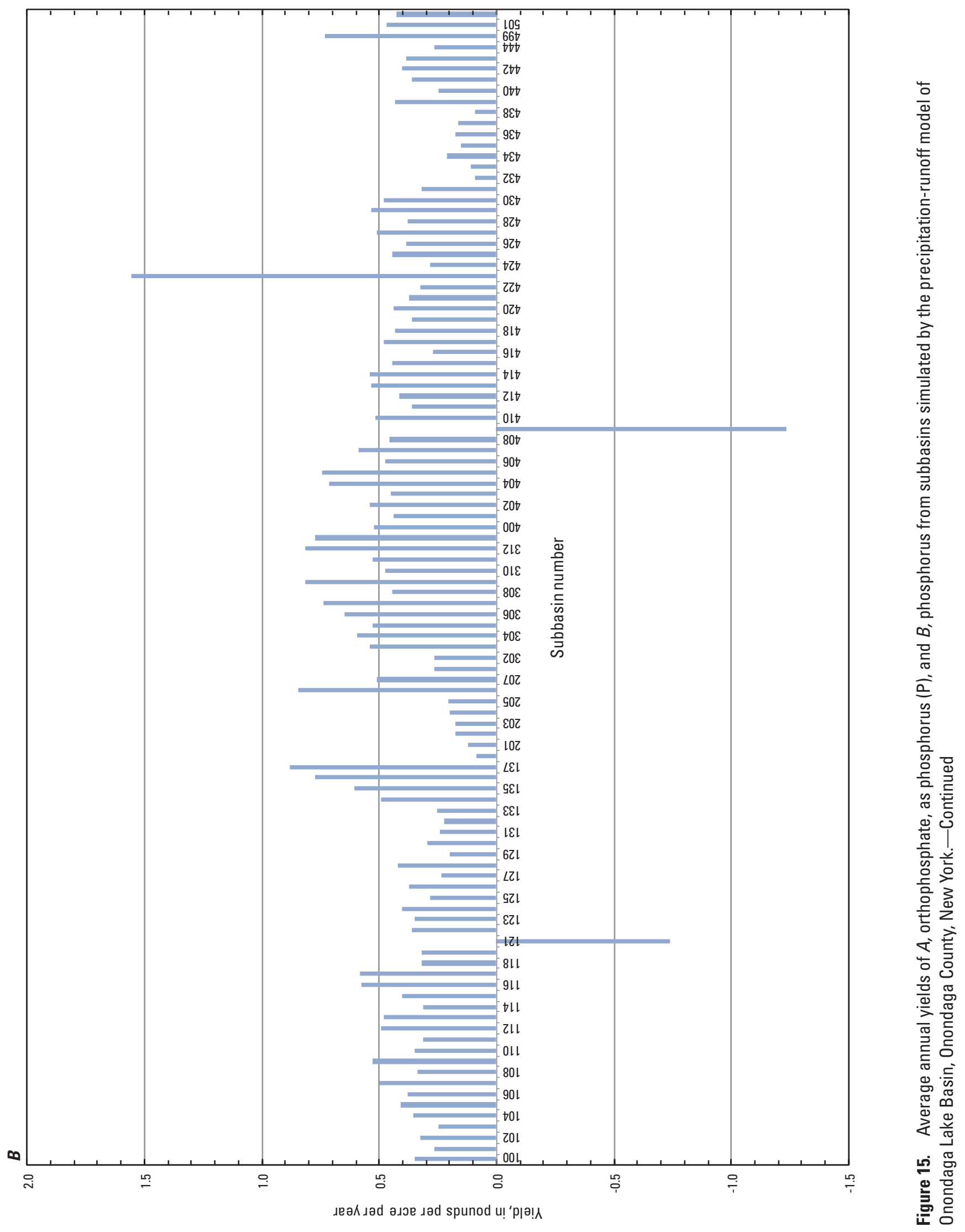




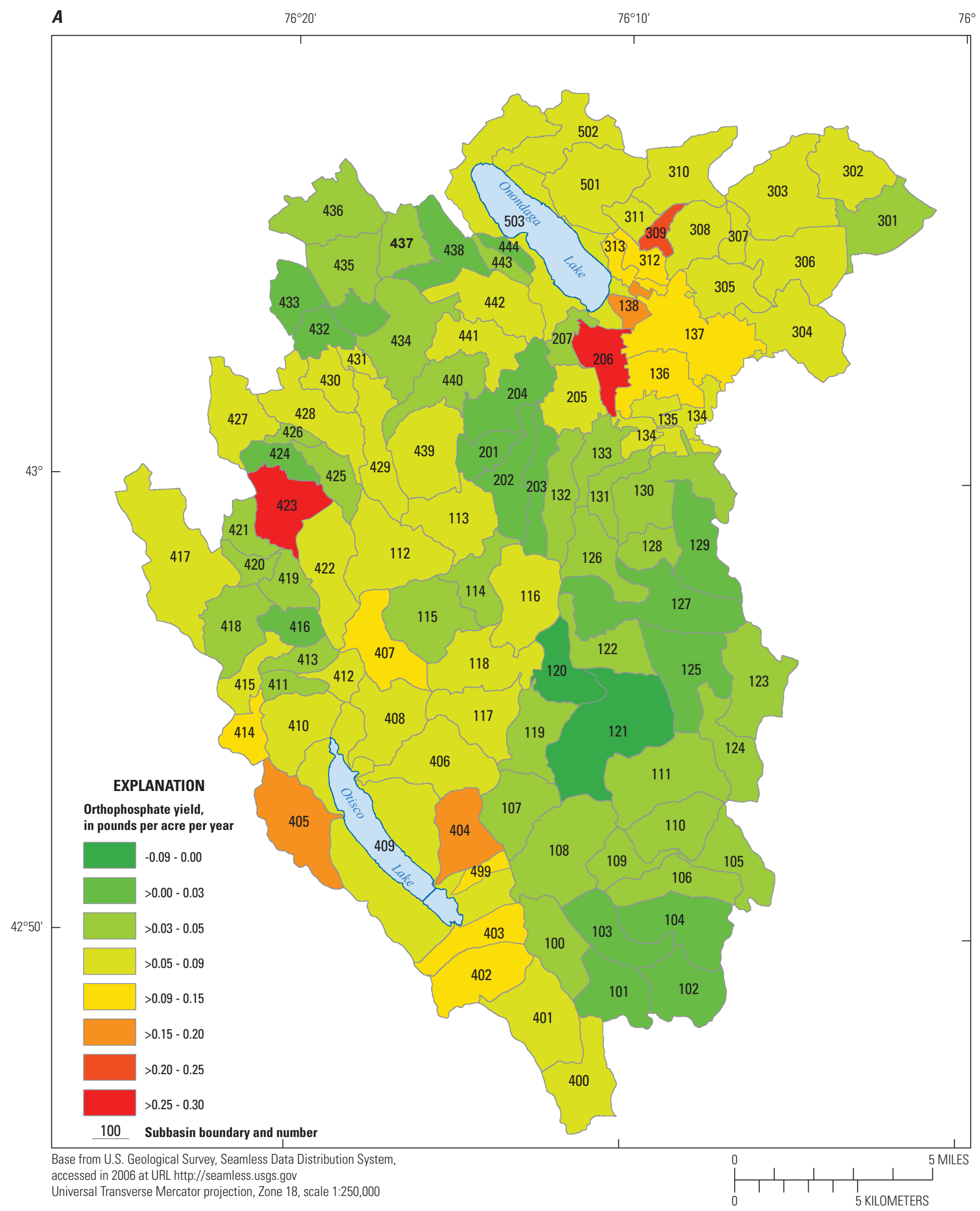

Figure 16. Orthophosphate, as phosphorus (P), $A$, average annual subbasin yields and $B$, estimated subbasin yields that enter Onondaga Lake, Onondaga County, New York. 


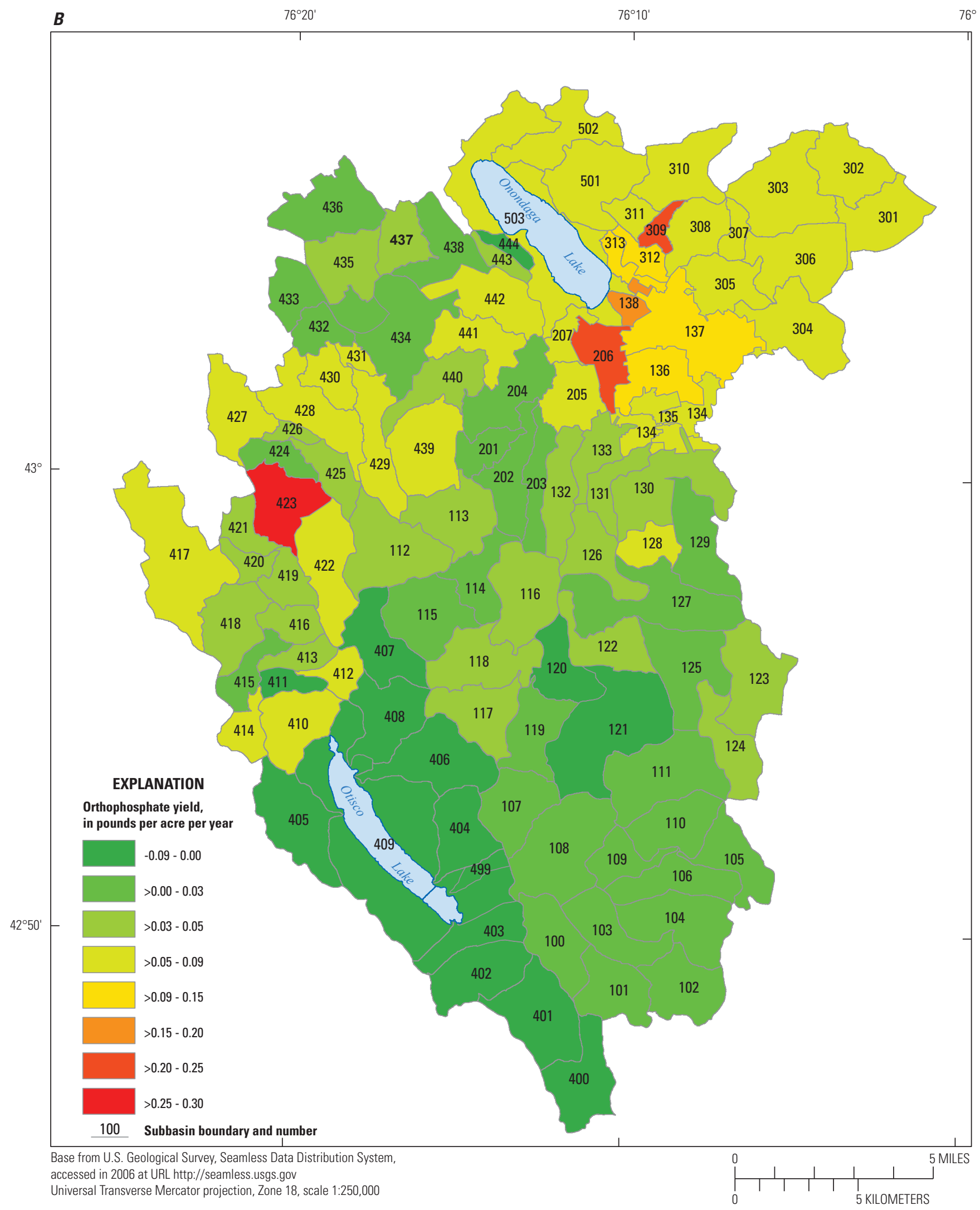

Figure 16. Orthophosphate, as phosphorus (P), $A$, average annual subbasin yields and $B$, estimated subbasin yields that enter Onondaga Lake, Onondaga County, New York.-Continued 


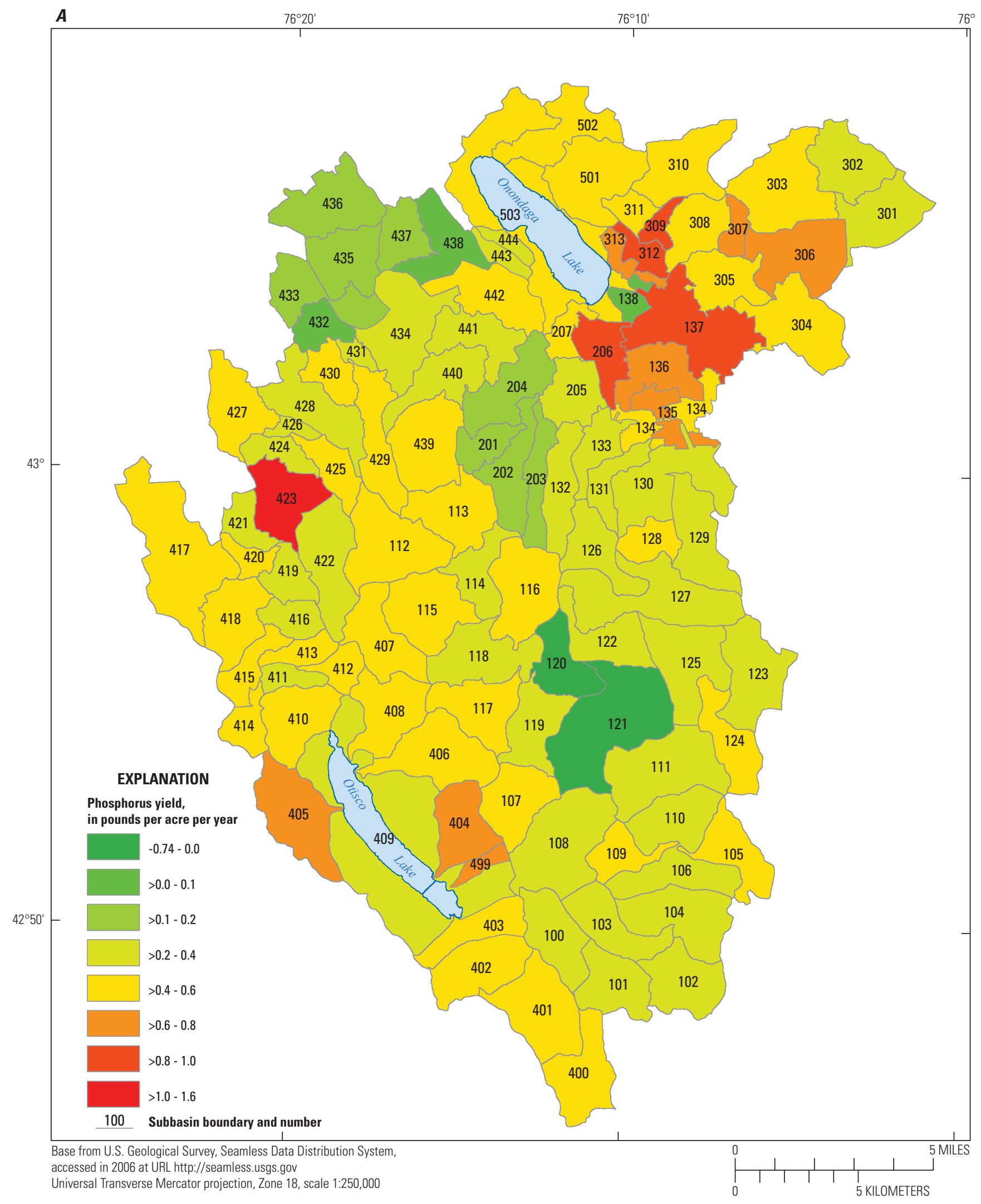

Figure 17. Phosphorus $A$, average annual subbasin yields and $B$, estimated subbasin yields that enter Onondaga Lake, Onondaga County, New York. 


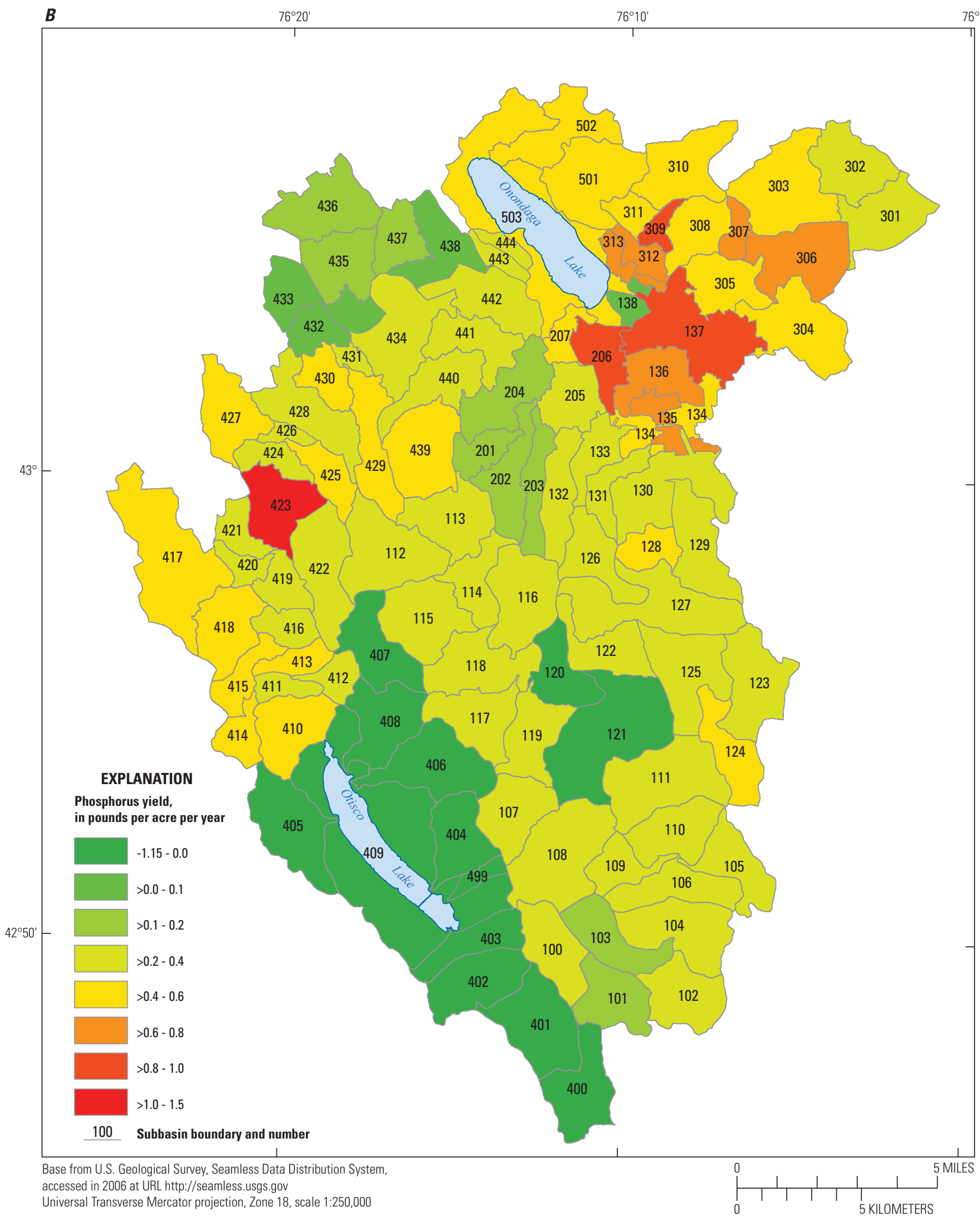

Figure 17. Phosphorus $A$, average annual subbasin yields and $B$, estimated subbasin yields that enter Onondaga Lake, Onondaga County, New York.-Continued 


\section{Chloride Loads in Onondaga Creek}

During the simulation period, $1998-2008$, the simulated annual loads of $\mathrm{Cl}$ in Onondaga Creek near Cardiff (site 04237962; fig. 1; table 1) and at Dorwin Avenue (04239000; fig. 1; table 1) were stable (fig. 18). The annual loads near Cardiff ranged from 8,600 to 9,400 short tons and the average annual load was 9,000 tons, whereas the annual loads at Dorwin Avenue ranged from 8,100 to 8,600 tons and the average annual load was 8,400 tons. Chloride loads more than quadrupled between Dorwin Avenue and Spencer Street (site 04240010; fig. 1; table 1) and increased again downstream from Spencer Street (fig. 18). As discussed previously, these increases are likely caused by springs that discharge brine to the creek; the spring downstream from Spencer Street flows at about 1 cubic foot per second and discharges almost 100,000 tons of sodium chloride annually (Yager and others, 2007). During 1998-2004, the simulated loads in Onondaga Creek at Spencer Street and at the mouth (reach 138; fig. 2) were also fairly stable; average annual loads were 41,000 and 72,000 tons, respectively. Starting in 2005, the loads at Spencer Street and at the mouth increased (fig. 18), presumably as a result of briny groundwater that was pumped to dewater sewer-construction sites in Syracuse and discharged to Onondaga Creek. By 2008, the simulated annual load of $\mathrm{Cl}$ had increased to 124,000 tons at Spencer Street and 155,000 tons at the mouth.

\section{Precolonization (Forested) Scenario}

To define the bounding condition that presumably would reflect no effects of human activities in the basin and therefore the lowest practicable limit of P loads to Onondaga Lake that could be attained by mitigation measures, the model was modified to create a scenario of precolonization (mostly forested) conditions. First, all agricultural, developed, and impervious land types were converted to forested land except in areas adjacent to Onondaga Lake; these areas were changed to wetlands as indicated on historical maps (on file in the Ithaca, N.Y., office of the U.S. Geological Survey). Second, the Onondaga Reservoir and its associated mitigative effects on sediment and particulate loads were removed. Third, the dam at the north end of Otisco Lake, as well as the withdrawals by Onondaga County Water Authority, were removed from the model; a new stage-discharge relation to reflect these changes was created. Fourth, all instructions pertaining to the simulation of the tunnel through which Harbor Brook flows for about half of its length in subbasin 206 (fig. 2) were removed. Finally, the nutrient inputs from the Marcellus wastewatertreatment plant were removed.

Under precolonization conditions, the probable combined average annual loads of OP and P from the four major tributaries to the lake would be 2.00 and 11.91 tons, respectively (table 7). These loads reflect overall decreases of 46 and 56 percent from present-day OP and P loads, respectively. For a given tributary, a completely forested basin presumably would generate 38 to 79 percent less OP and 47 to 81 percent less $\mathrm{P}$ on an average annual basis than is generated and transported to Onondaga Lake currently (1998-2008).

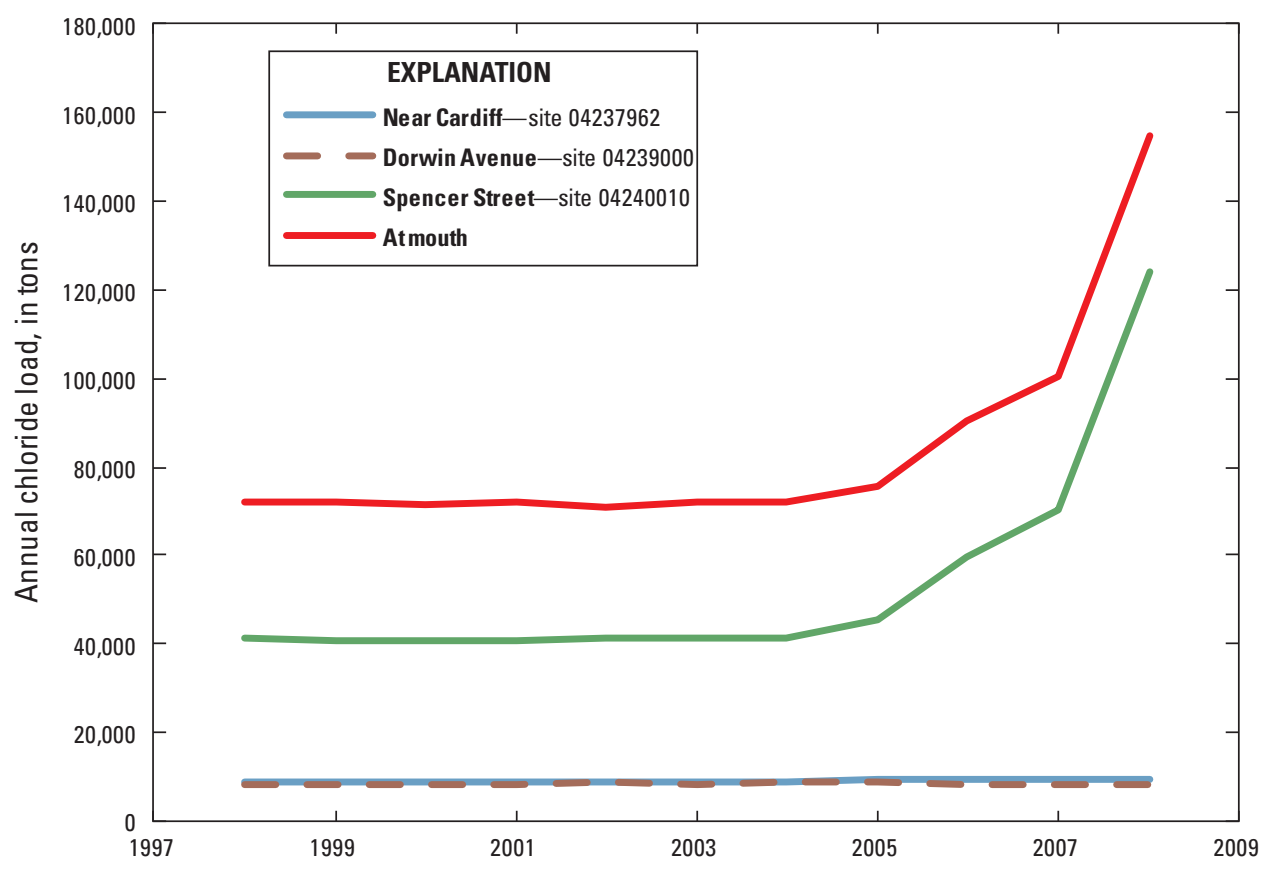

Figure 18. Annual chloride loads simulated at four sites along Onondaga Creek by the precipitation-runoff model of Onondaga Lake Basin, Onondaga County, New York. 
Table 7. Average annual orthophosphate, as phosphorus (P), and phosphorus loads simulated in tributaries to Onondaga Lake by the precipitation-runoff model of Onondaga Lake Basin, Onondaga County, New York, under current (1998-2008) and precolonization (forested) conditions.

\begin{tabular}{|c|c|c|c|c|c|c|c|}
\hline \multirow[b]{2}{*}{ Tributary } & \multirow[b]{2}{*}{$\begin{array}{l}\text { Drainage area, } \\
\text { in square miles }\end{array}$} & \multicolumn{3}{|c|}{ Orthophosphate, as P, load, short tons } & \multicolumn{3}{|c|}{ Total phosphorus load, tons } \\
\hline & & Current & Forested & $\begin{array}{c}\text { Percent } \\
\text { difference }\end{array}$ & Current & Forested & $\begin{array}{c}\text { Percent } \\
\text { difference }\end{array}$ \\
\hline Onondaga Creek & 111 & 1.29 & 0.81 & -38 & 11.06 & 5.91 & -47 \\
\hline Harbor Brook & 12.1 & .24 & .05 & -79 & 1.11 & .26 & -77 \\
\hline Ley Creek & 30.0 & .63 & .29 & -55 & 4.62 & .86 & -81 \\
\hline Ninemile Creek & 115 & 1.55 & .85 & -45 & 10.03 & 4.88 & -51 \\
\hline Sum & & 3.71 & 2.00 & -46 & 26.82 & 11.91 & -56 \\
\hline
\end{tabular}

\section{Summary}

During 2003-07, the U.S. Geological Survey (USGS), in cooperation with the Onondaga Lake Partnership (OLP), developed a basin-scale precipitation-runoff model of the 285-square-mile Onondaga Lake Basin with the computer program, Hydrological Simulation Program-Fortran (HSPF), which simulated streamflows and loads of sediment, phosphorus, and nitrogen in the major tributaries of Onondaga Lake. The model was intended to provide water-resource managers with a tool to better understand the processes responsible for the generation of loads of sediment and nutrients that were transported to Onondaga Lake. This objective was only partly attained because data for calibration of the model were available from monitoring sites only at or near the mouths of the major tributaries to Onondaga Lake; no calibration data from headwater subbasins where loads originated were available. To address this limitation and thereby decrease the uncertainty in the simulation results that were associated with headwater processes, the USGS undertook a 3-year (2005-08) basinwide study to assess the quality of surface water in the Onondaga Lake Basin. Streamflow and water-quality data that were collected at 25 sites in the basin enabled assessment of the relative contributions of nonpoint sources associated with the major land uses in the basin, as well as known sources and presumed sinks of sediment and nutrient loads, which previously had not been evaluated. The newly acquired data from the nonpoint-source study were used to recalibrate the components of the model that simulated streamflow, water temperature, and suspended-sediment, orthophosphate, and phosphorus concentrations.

Prior to recalibration, all input datasets were extended 5 years from the end of the original model's simulation period, from October 1, 2003, through September 30, 2008. An existing subbasin was divided to permit direct calibration of the effects of a farmstead that dominated the water-quality characteristics of a small part of the original subbasin; the new subbasin was monitored during the nonpoint-source study. Land-use and land-cover acreages for 1992 (used in the original model) and 2001 were compared, and acreages in 13 urbanized subbasins were converted from forest and wetland to developed land uses as necessary for the recalibrated model. The hydrologic response units (HRUs) included in the model were revised by the removal of a high-sedimentyield agricultural HRU and the additions of an HRU that represented landslides in the Rattlesnake Gulf subbasin and a set of developed HRUs in the Harbor Brook subbasin. The mitigative effects of Onondaga Reservoir and Otisco Lake were assessed, and the effects related to the Onondaga Reservoir were incorporated into the model.

Model parameter values in the original 2003 model were revised as necessary to minimize the differences between simulated data and the newly acquired observed data from the nonpoint-source study. The resultant 2008 version of the model improved the simulation of processes in the headwater subbasins, including overland and groundwater flow, and the generation and transport of suspended-sediment, orthophosphate, and phosphorus. The fit between simulated and observed streamflows in small subbasins was improved by matching base flows, storm peaks, and storm recessions more precisely than had been possible with the original model. Simulated recessional and low flows were either increased or decreased as appropriate for a given stream, and peak flows generally were decreased in the 2008 model. The use of suspended-sediment (SS) data in the 2008 model rather than the surrogate constituent, total suspended solids (TSS), resulted in increases in simulated sediment concentrations in low flows and, in most cases, decreases in peak-flow concentrations. Simulated orthophosphate (OP) concentrations in base flows generally increased, and those for peak flows decreased, for selected headwater subbasins in the 2008 model. Phosphorus (P) concentrations simulated by the 2008 model for forested 
subbasins were relatively close to those simulated by the 2003 model. Phosphorus concentrations generally decreased in developed and wetland-dominated subbasins but increased in agricultural subbasins. In addition to the changes mentioned above, the 2008 model also included the simulation of chloride concentrations in the Onondaga Creek Basin only.

The recalibrated 2008 model generated output that was used to (1) compute loading rates for the land types that were simulated in the model, (2) conduct a watershed-management analysis that estimated the portion of the total subbasin load that was likely to be transported to Onondaga Lake, and (3) compute and assess chloride (salt) loads to Onondaga Lake from the Onondaga Creek Basin. Additionally, the use of the model for scenario development and subsequent comparison of before-and-after model outputs was demonstrated by the simulation of precolonization (forested) conditions in the basin to estimate the probable minimum phosphorus loads to the lake.

Farmstead and row-crop land uses produced the highest simulated loading rates of SS, OP, and organic phosphorus (OrgP). The lowest sediment loading rates were from wetlands, followed by forested land with high infiltration rates and low runoff potentials. Forests had the lowest loading rates of both OP and OrgP.

Yields of OP and P generally were high in subbasins with large areas of agricultural or developed land. The largest sediment yields were associated with basins in which landslides and erosional problems had been identified. Negative yields were computed for Onondaga Reservoir and Otisco Lake. Subbasins that generated large yields of OP or P, but were distant from Onondaga Lake, were less likely to make substantial contributions to the total load entering the lake than subbasins proximal to the lake. Conversely, most of the yields from urbanized subbasins close to the lake made relatively large contributions to the lake's total input loads.

Simulated loads of chloride in Onondaga Creek increased dramatically in Syracuse between Dorwin Avenue at the southern boundary of the city and Spencer Street, about 5 miles downstream. Another large increase occurred downstream from Spencer Street and was evident in simulated results for the next reach downstream at the mouth of the creek. The presumed or documented sources of these loads are springs that discharge groundwater brine to the creek. On the basis of simulated loads for the period 1998-2004, the average annual load of $\mathrm{Cl}$ in Onondaga Creek increased from 9,000 tons near Cardiff to 72,000 tons at the creek's mouth. A time-trend analysis of chloride loads indicated a large increase in chloride inputs to Onondaga Lake starting in 2005.

A simulation scenario was developed wherein all humanrelated activities (agriculture and development) were removed from the Onondaga Lake Basin and the land was returned to precolonization conditions of forests and wetlands. Under this scenario, the probable combined average annual loads of OP and $\mathrm{P}$ from the four major tributaries to the lake would be 2.00 and 11.91 tons, respectively, or an overall decrease of 46 and 56 percent from present-day OP and P loads, respectively.

\section{References Cited}

Bicknell, B.R., Imhoff, J.C., Kittle, J.L. Jr., Jobes, T.H., and Donigian, A.S., Jr., 2001, Hydrological Simulation Program-Fortran, version 12, user's manual: Athens, Ga., U.S. Environmental Protection Agency, National Exposure Research Laboratory, Office of Research and Development, 873 p., accessed April 15, 2005, at http://www.epa.gov/ docs/ostwater/BASINS/bsnsdocs.html\#hspf.

Bloomfield, J.A., 1978, Lakes of New York State, v. I, Ecology of the Finger Lakes: New York, Academic Press, 499 p.

Callinan, C.W., 2001, Water quality study of the Finger Lakes: New York State Department of Environmental Conservation, 152 p., accessed February 2005, at http://www.dec.state.ny.us/website/dow/fingerlakes/.

Cohn, T.A., 1988, Adjusted maximum likelihood estimation of the moments of lognormal populations from type I censored samples: U.S. Geological Survey Open-File Report 88-350, 34 p.

Cohn, T.A., Caulder, D.L., Gilroy, E.J., Zynjuk, L.D., and Summers, R.M., 1992, The validity of a simple statistical model for estimating fluvial constituent loadsAn empirical study involving nutrient loads entering Chesapeake Bay: Water Resources Research, v. 28, no. 9, p. 2353-2363.

Coon, W.F., 2008, Simulation of streamflow and selected water-quality constituents through a model of the Onondaga Lake Basin, Onondaga County, New York-A guide to model application: U.S. Geological Survey Open-File Report 2008-1188, 27 p.

Coon, W.F., Hayhurst, B.A., Kappel, W.M., Eckhardt, D.A.V., and Szabo, C.O., 2009, Water-quality characterization of surface water in the Onondaga Lake Basin, Onondaga County, New York, 2005-08: U.S. Geological Survey Scientific Investigations Report 2009-5246, 67 p.

Coon, W.F., and Reddy, J.E., 2008, Hydrologic and waterquality characterization and modeling of the Onondaga Lake Basin, Onondaga County, New York: U.S. Geological Survey Scientific Investigations Report 2008-5013, 85 p.

DeGaetano, A.T., and Wilks, D.S., 2008, Radar-guided interpolation of climatological precipitation data: International Journal of Climatology, accessed January 2009, at http://www3.interscience.wiley.com/cgi-bin/ fulltext/119139895/PDFSTART. 
Donigian, A.S., Jr., 2002, Watershed model calibration and validation-The HSPF experience: Water Environment Federation National TMDL Science and Policy 2002: Phoenix, Ariz., November 13-16, 2002, Specialty Conference Proceedings, 30 p., accessed September 2003, at http://www.aquaterra.com/TMDL.Nov02.Donigian.Paper. doc.

Effler, S.W., and Hennigan, R.D., 1996, Onondaga Lake, New York-Legacy of pollution: Lake and Reservoir Management, v. 12, no. 1, p. 1-13.

Effler, S.W., and Whitehead, K.A., 1996, Tributaries and discharges (chap. 3), in Effler, S.W., ed., Limnological and engineering analysis of a polluted urban lake: Prelude to environmental management of Onondaga Lake, New York: New York, Springer-Verlag, p. 97-199.

Hamon, W.R., 1961, Estimating potential evapotranspiration: Proceedings of the American Society of Civil Engineers, Journal of the Hydraulic Division, v. 87, no. HY3, p. 107-120.

Hayhurst, B.A., Coon, W.F., and Eckhardt, D.A.V., 2010, Water resources of Monroe County, New York, water years 2003-08: Streamflow, constituent loads, and trends in water quality: U.S. Geological Survey Scientific Investigations Report 2010-5216, 34 p. (Also available at http://pubs.usgs.gov/sir/2010/5216.)

Kappel, W.M., 2000, Salt production in Syracuse, New York ("The Salt City") and the hydrogeology of the Onondaga Creek valley: U.S. Geological Survey Fact Sheet 139-00, $8 \mathrm{p}$.

Kappel, W.M., 2009, Remediation of mudboil discharges in the Tully Valley of central New York: U.S. Geological Survey Open-File Report 2009-1173, 8 p.

Kappel, W.M., and McPherson, W.S., 1998, Remediation of mudboil discharges in the Tully Valley of central New York: U.S. Geological Survey Fact Sheet 143-97, 4 p.

McKenna, J.E., Chiotti, T.L., and Kappel, W.M., 1999, Ecological status of Onondaga Creek in Tully Valley, New York-Summer 1998: U.S. Geological Survey Fact Sheet 141-99, 6 p.

National Weather Service, 2011, Annual temperature, precipitation, and snowfall data, Syracuse, New York: National Weather Service Forecast Office, Binghamton, N.Y., accessed June 22, 2011, at http://www.erh.noaa.gov/ bgm/climate/syr/syr_annual_totals.shtml.

New York State Department of Environmental Conservation, 1999, Regulatory freshwater wetlands for Onondaga County: New York State Department of Environmental Conservation, accessed July 2003, from Cornell University Geospatial Information Repository (CUGIR) at http://cugir.mannlib.cornell.edu/bucketinfo.jsp? $\mathrm{id}=470$.
Paschal, J.E., Jr., and Sherwood, D.A., 1987, Relation of sediment and nutrient loads to watershed characteristics and land use in the Otisco Lake Basin, Onondaga County, New York: U.S. Geological Survey Water-Resources Investigations Report 86-4026, 62 p.

Runkel, R.L., Crawford, C.G., and Cohn, T.A., 2004, Load estimator (LOADEST): A FORTRAN program for estimating constituent loads in streams and rivers: U.S. Geological Survey Techniques and Methods, book 4, chap. A5, 69 p. (Also available at http://pubs.usgs.gov/tm/2005/tm4A5/.)

Tamulonis, K.L., Kappel, W.M., and Shaw, S.B., 2009, Causes and movement of landslides at Rainbow Creek and Rattlesnake Gulf in the Tully Valley, Onondaga County, New York: U.S. Geological Survey Scientific Investigations Report 2009-5114, 18 p. (Also available at http://pubs.usgs.gov/sir/2009/5114/.)

Thiessen, A.H., 1911, Precipitation for large areas: Monthly Weather Review, v. 39, no. 7, p. 1082-1084.

Upstate Freshwater Institute, 2010, Onondaga Lake: Upstate Freshwater Institute, accessed December 15, 2010, at http://www.upstatefreshwater.org/html/onondaga_lake.html.

U.S. Army Corps of Engineers, 1945, Design analysis for Onondaga Reservoir, Onondaga Creek, New York: Syracuse, N.Y., U.S. Army Corps of Engineers, 185 p.

U.S. Fish and Wildlife Service, 2000, National Wetlands Inventory: U.S. Fish and Wildlife Service, accessed March 2000, at http://www.nwi.fws.gov/maps.

U.S. Geological Survey, 1999, National land cover data, New York: U.S. Geological Survey, accessed April 2003, at New York State GIS Clearinghouse at http://www.nysgis.state.ny.us.

U.S. Geological Survey, 2005, Multi-Resolution Land Characteristics Consortium: U.S. Geological Survey, accessed February 2005, at http://www.mrlc.gov/.

U.S. Geological Survey, 2008, USGS Water data for the nation: U.S. Geological Survey, National Water Information System, accessed December 1, 2008, at http://waterdata.usgs.gov/nwis/.

U.S. Geological Survey, 2009, U.S. Geological Survey Automated Data Processing System (ADAPS): U.S. Geological Survey, data downloaded January 23, 2009.

Yager, R.M., Kappel, W.M., and Plummer, L.N., 2007, Halite brine in the Onondaga Trough near Syracuse, New YorkCharacterization and simulation of variable-density flow: U.S. Geological Survey Scientific Investigations Report 2007-5058, 40 p. 
Prepared by the Pembroke Publishing Service Center.

For additional information write to:

New York Water Science Center

U.S. Geological Survey

30 Brown Rd.

Ithaca, NY 14850

Information requests:

(518) 285-5602

or visit our Web site at:

http://ny.water.usgs.gov 


\section{앴}

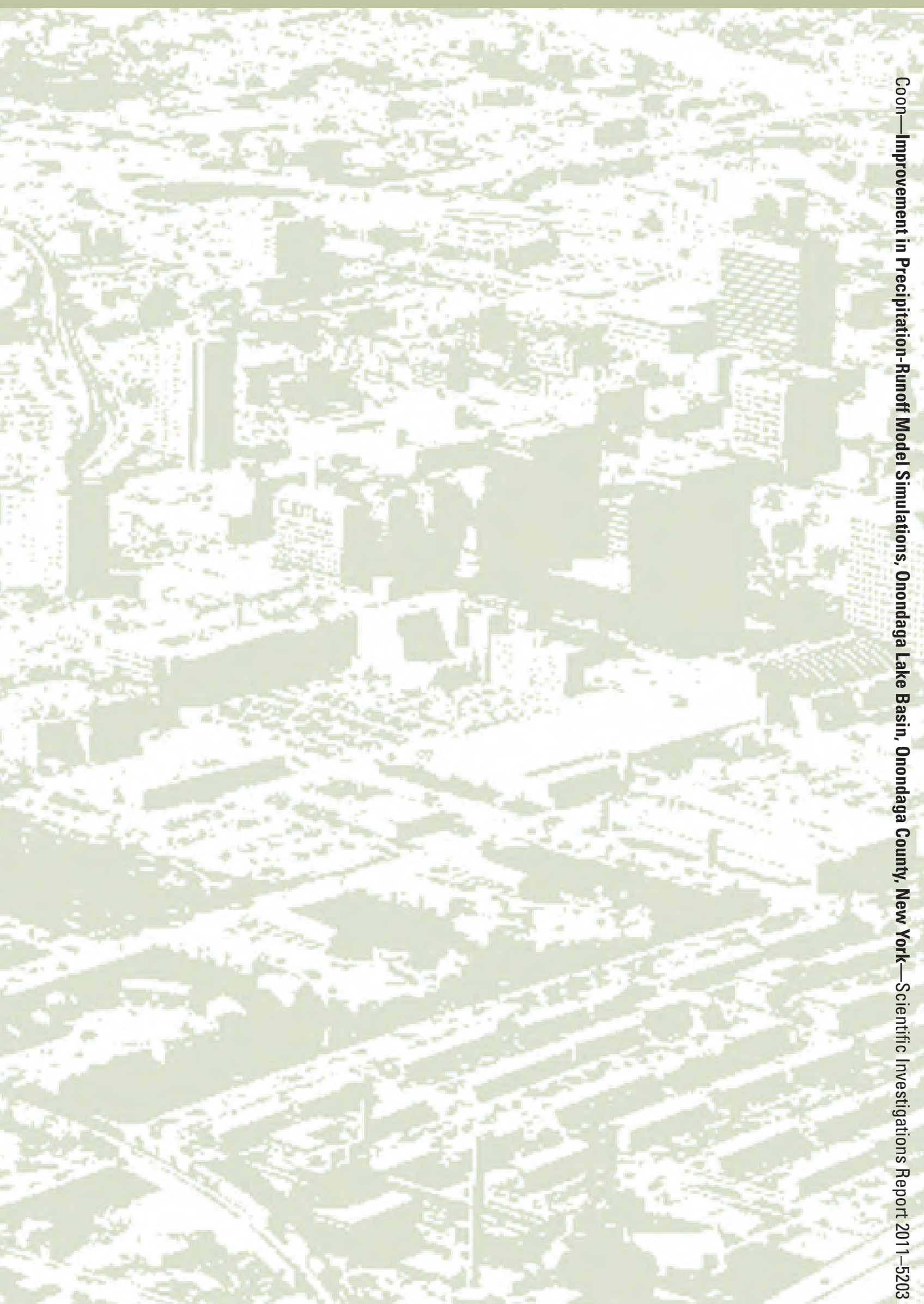

